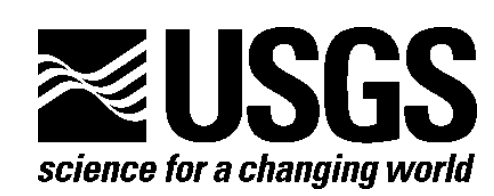

\title{
Geologic Map of the Sauvie Island Quadrangle, Multnomah and Columbia Counties, Oregon, and Clark County, Washington
}

By Russell C. Evarts, Jim E. O'Connor, and Charles M. Cannon

Pamphlet to accompany

Scientific Investigations Map 3349

2016

U.S. Department of the Interior

U.S. Geological Survey 


\section{U.S. Department of the Interior \\ SALLY JEWELL, Secretary}

\section{U.S. Geological Survey \\ Suzette M. Kimball, Director}

U.S. Geological Survey, Reston, Virginia: 2016

For more information on the USGS - the Federal source for science about the Earth, its natural and living resources, natural hazards, and the environment-visit http://www.usgs.gov or call 1-888-ASK-USGS

For an overview of USGS information products, including maps, imagery, and publications, visit http://www.usgs.gov/pubprod

To order this and other USGS information products, visit http://store.usgs.gov

Any use of trade, product, or firm names is for descriptive purposes only and does not imply endorsement by the U.S. Government.

Although this report is in the public domain, permission must be secured from the individual copyright owners to reproduce any copyrighted material contained within this report.

Suggested citation:

Evarts, R.C., O'Connor, J.E., and Cannon, C.M., 2016, Geologic map of the Sauvie Island quadrangle, Multnomah and Columbia Counties, Oregon, and Clark County, Washington: U.S. Geological Survey Scientific Investigations Map 3349, scale 1:24,000, pamphlet 34 p., http://dx.doi.org/10.3133/sim3349.

ISSN 2329-132X (online) 


\section{Contents}

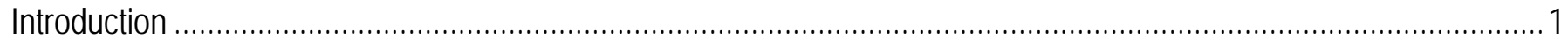

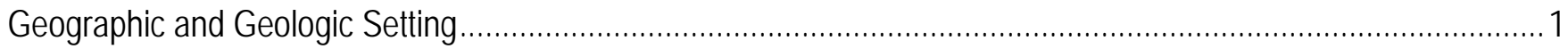

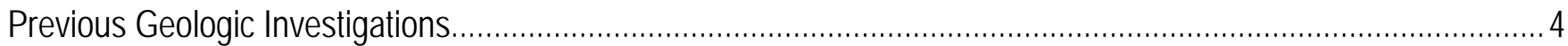

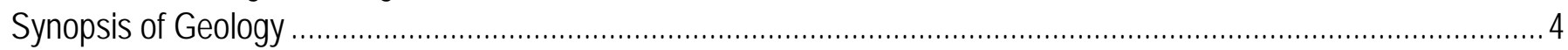

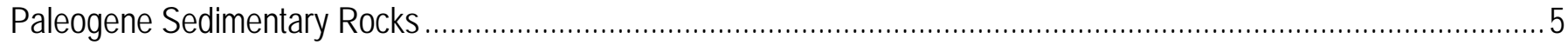

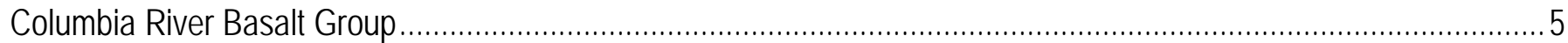

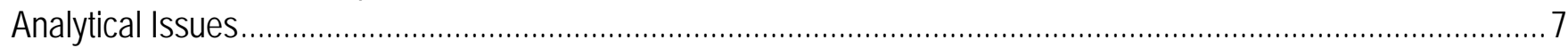

Grande Ronde Basalt in the Sauvie Island Quadrangle ……...............................................................

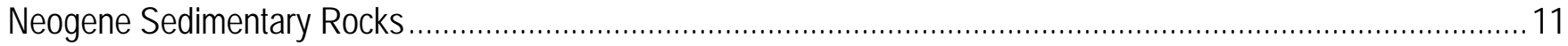

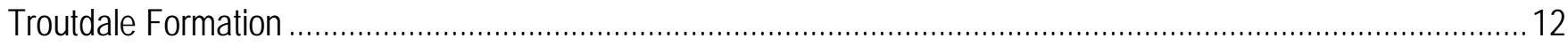

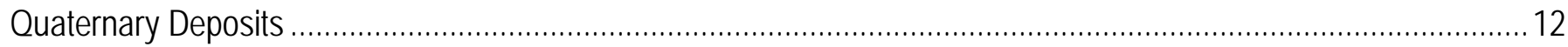

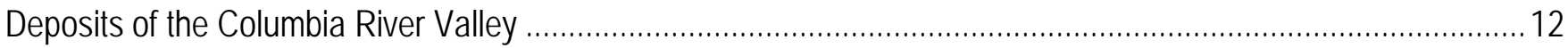

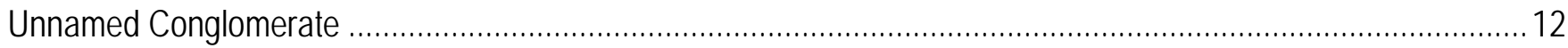

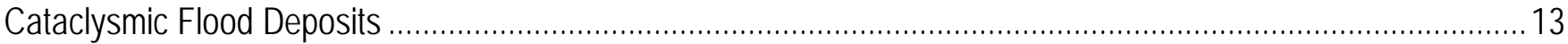

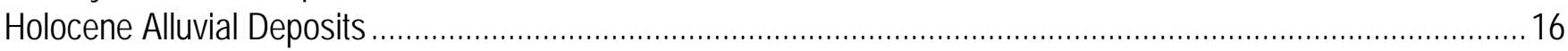

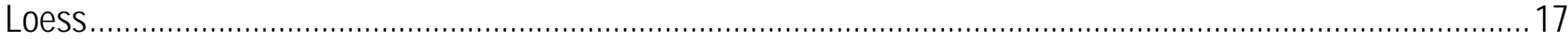

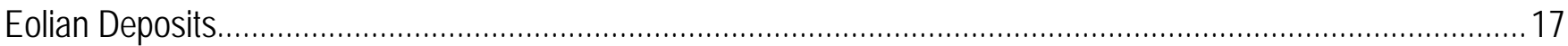

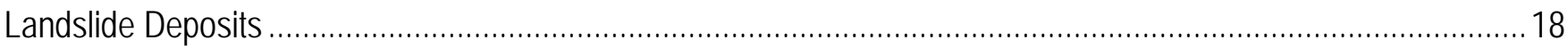

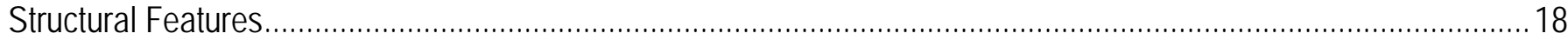

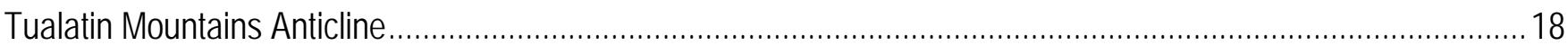

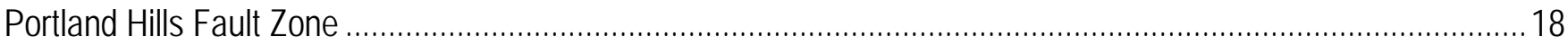

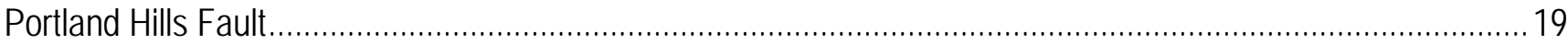

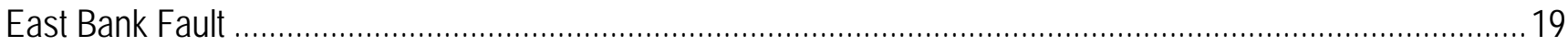

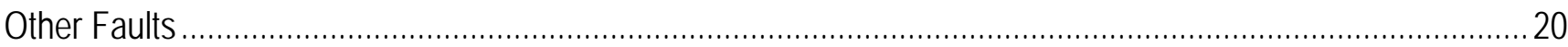

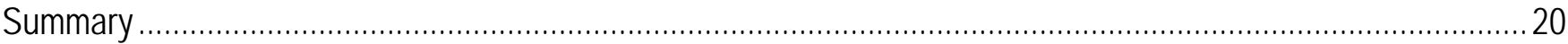

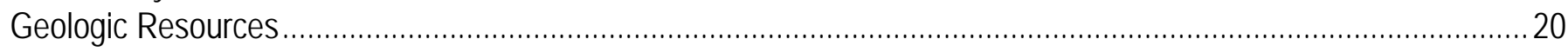

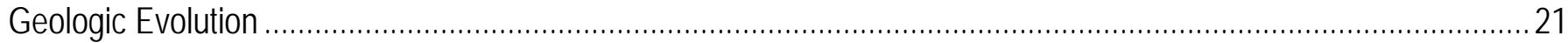

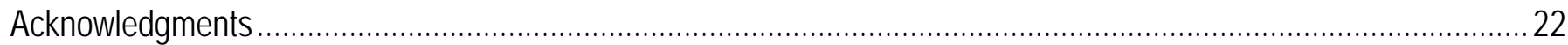

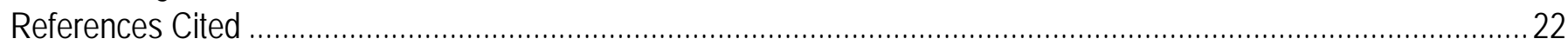

\section{Figures}

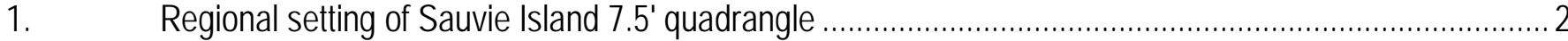

2. Stratigraphic nomenclature, ages, and magnetic polarities of the Columbia River Basalt Group................ 6

3. Chemical characteristics of Grande Ronde Basalt flows in Sauvie Island quadrangle ................................ 8

4. Paleomagnetic directions for Grande Ronde Basalt flows in Sauvie Island quadrangle ........................... 10

5. Estimated elevation of top of the unnamed conglomerate (QTc) in Sauvie Island quadrangle and

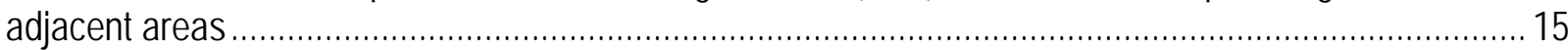

\section{Tables}

1. Chemical analyses of the Grande Ronde Basalt, Sauvie Island quadrangle...........................................29

2. Paleomagnetic data for Columbia River Basalt flows, Sauvie Island quadrangle.................................... 32

3. Summary of luminescence age determinations in vicinity of Sauvie Island quadrangle. ............................. 33

4. Summary of radiocarbon age determinations, Sauvie Island quadrangle ................................................. 34 
Vertical coordinate information is referenced to the North American Vertical Datum of 1988 (NAVD 88).

Map boundary coordinates are referenced to the North American Datum of 1927 (NAD 27). All other horizontal coordinate information is referenced to the North American Datum of 1983 (NAD 83).

Altitude, as used in this report, refers to distance above the vertical datum. 


\title{
Geologic Map of the Sauvie Island Quadrangle, Multnomah and Columbia Counties, Oregon, and Clark County, Washington
}

\author{
By Russell C. Evarts, Jim E. O'Connor, and Charles M. Cannon
}

\section{Introduction}

\section{Geographic and Geologic Setting}

The Sauvie Island 7.5' quadrangle is situated in the Puget-Willamette Lowland northwest of downtown Portland, Oreg. (fig. 1). This lowland, which extends from Puget Sound to west-central Oregon, is a complex structural and topographic trough between the Coast Range and the Cascade Range. Since late Eocene time, the Cascade Range has been the locus of a discontinuously active volcanic arc associated with underthrusting of oceanic lithosphere beneath the North American continent along the Cascadia Subduction Zone. The Coast Range, which occupies the fore-arc position within the Cascadia arc-trench system, consists of a complex assemblage of Eocene to Miocene volcanic and marine sedimentary rocks.

The Sauvie Island quadrangle encompasses the western margin of the Portland Basin, a 2,000$\mathrm{km}^{2}$ topographic and structural depression. The Portland Basin is the northernmost of several sedimentfilled structural basins that constitute the Willamette Valley segment of the Puget-Willamette Lowland (Beeson and others, 1989; Swanson and others, 1993; Yeats and others, 1996). The rhomboidal basin is about $70 \mathrm{~km}$ long and $30 \mathrm{~km}$ wide, its long dimension oriented northwest. The Columbia River flows west and north through the Portland Basin at nearly sea level, and it exits through a bedrock valley less than $2.5 \mathrm{~km}$ wide about $25 \mathrm{~km}$ north of Scappoose, Oreg. The Willamette River enters the Columbia near the southeast corner of the map area. A secondary distributary of the Willamette River, Multnomah Channel, which defines the west boundary of Sauvie Island, joins the Columbia River north of the map area.

The uplifted flanks of the basin consist of Eocene through Miocene volcanic and sedimentary rocks that rise above $610 \mathrm{~m}$. Seismic-reflection profiles (L.M. Liberty, written commun., 2003) and lithologic logs of water wells (Swanson and others, 1993; Mabey and Madin, 1995) show as much as $550 \mathrm{~m}$ of late Miocene and younger sediments in the deepest part of the basin near Vancouver, Wash. Most of this basin fill was carried in from the east by the Columbia River, but some came from streams that drain the adjacent highlands (Evarts and others, 2009a). The southwest boundary of the Portland Basin is an abrupt topographic break along the base of the Tualatin Mountains, an asymmetric anticlinal ridge between the Portland and Tualatin Basins (fig. 1B). The Tualatin Mountains Anticline is associated with several northwest-striking faults that constitute the Portland Hills Fault Zone of Blakely and others (1995). Some of these faults have ruptured in the Quaternary (Madin and Hempill-Haley, 2001; Wong and others, 2001; Liberty and others, 2003; Walsh and others, 2011).

This map contributes to a U.S. Geological Survey (USGS) program to improve the geologic

database for the Portland region of the Pacific Northwest urban corridor. The map and ancillary data will 
support assessments of seismic risk (Yelin and Patton, 1991; Bott and Wong, 1993), ground-failure hazards (Madin and Wang, 1999; Wegmann and Walsh, 2001), and resource availability.

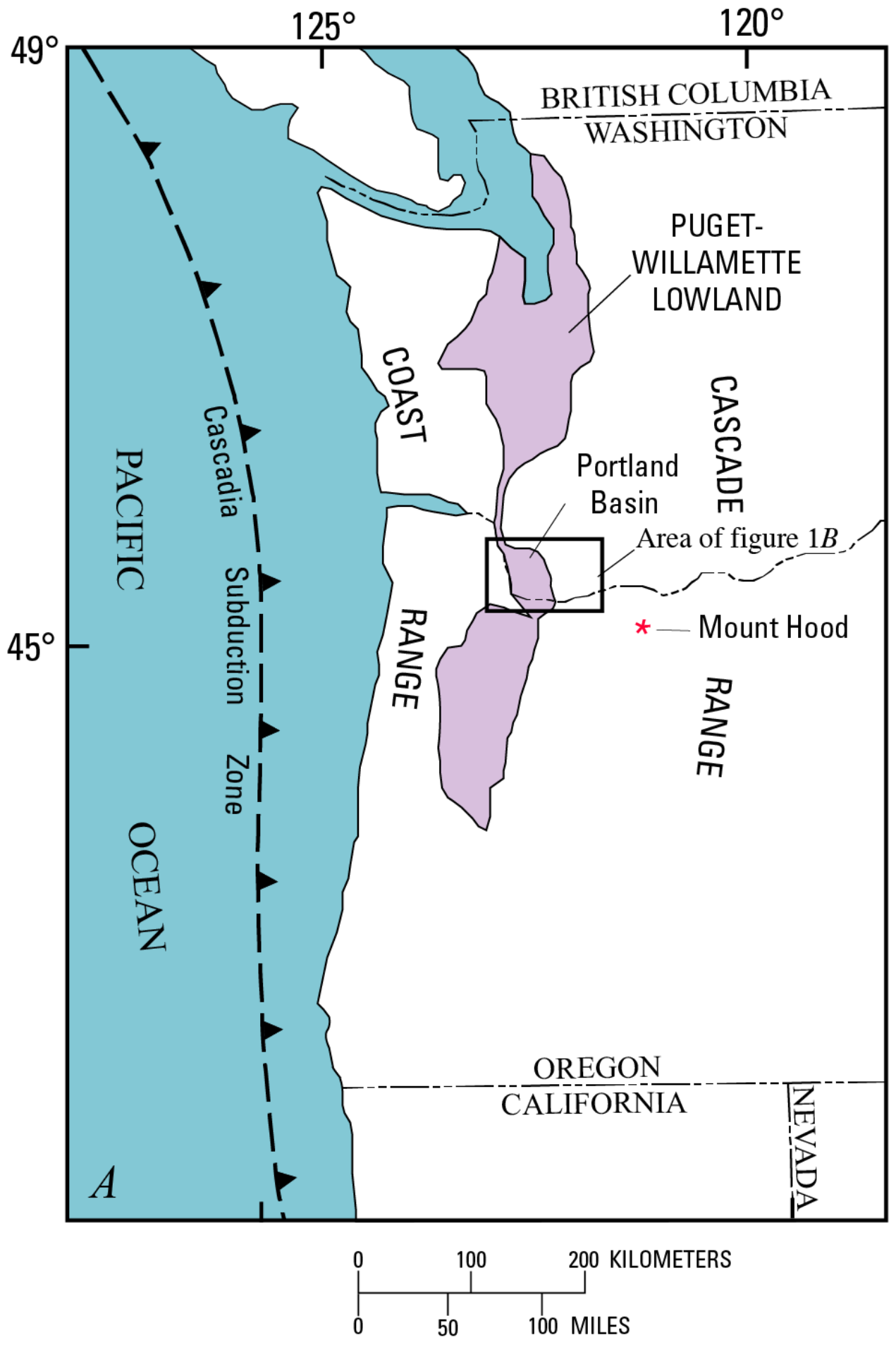

Figure 1. Regional setting of Sauvie Island $7.5^{\prime}$ quadrangle. $A$, Map showing major tectonic and physiographic features of Pacific Northwest in relation to Cascadia Subduction Zone (sawteeth on upper plate). $B$, Simplified geologic map of Vancouver 30' × 60' quadrangle, modified from Phillips (1987a). 

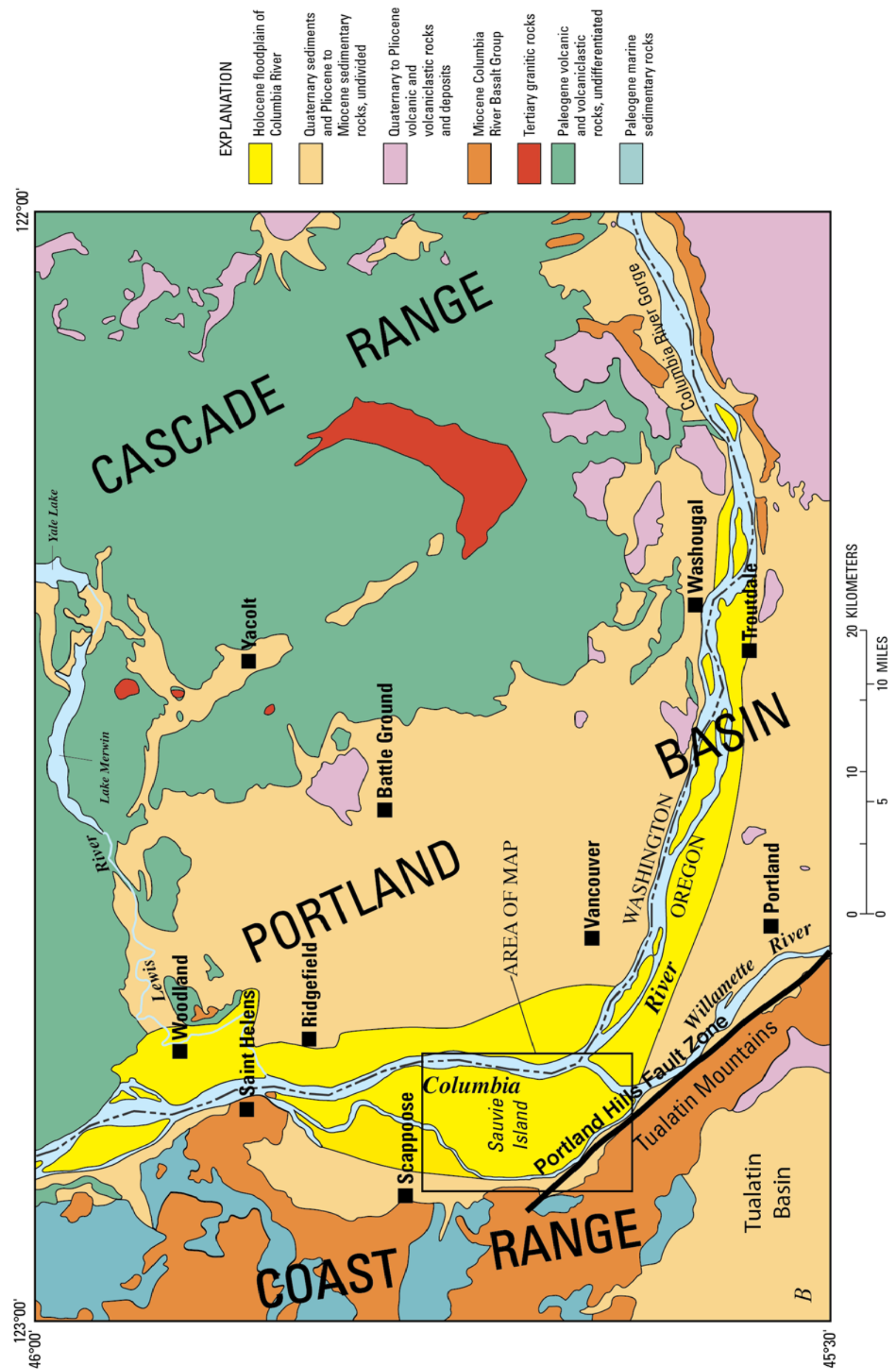

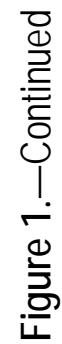




\section{Previous Geologic Investigations}

The general stratigraphic framework and distribution of geologic units in the quadrangle is shown on Trimble's (1963) 1:62,500-scale map of the Portland metropolitan area, which shows that Miocene basalt flows of the Columbia River Basalt Group underlie most of the upland terrain and that deposits of the Columbia River and major tributaries underlie the lowlands.

Recently, several adjacent quadrangles (Portland to the southeast, Saint Helens to the north, Ridgefield to the northeast, Dixie Mountain to the west, and Linnton to the south) were mapped at 1:24,000 scale (Beeson and others, 1991; Evarts, 2004a,b; Madin and Niewendorp, 2008; Madin and others, 2008). A major advance reflected in these maps is the use of high-quality chemical and paleomagnetic data to divide the Columbia River Basalt Group into formations and members as defined east of the Cascade Range by Swanson and others (1979), Beeson and others (1985), Reidel and others (1989), and Reidel and Tolan (2013).

Several topical investigations of regional scope also provide information on the geology of the Sauvie Island quadrangle and adjacent areas: Libbey and others (1945), on ferruginous-bauxite occurrences; Lowry and Baldwin (1952), on late Cenozoic deposits of the Columbia River; Mundorff (1964) and Swanson and others (1993), on water resources; Lentz (1981), on eolian deposits; and Blakely and others (1995, 2000), on structural interpretations of aeromagnetic surveys. Investigations of subsurface geology beneath the Columbia River floodplain were undertaken by Gates (1994), Ryan and Stephenson (1995), and Pratt and others (2001).

\section{Synopsis of Geology}

The Columbia River floodplain occupies most of the Sauvie Island quadrangle. Deposits at and near the floodplain consist mainly of upper Holocene sediment, but older Quaternary gravel terraces and eolian deposits both locally flank and emerge through the floodplain deposits. Bedrock and preHolocene sedimentary deposits underlie most of the upland in the western part of the map area, although some uplands are capped by cataclysmic-flood sediment and thick accumulations of Quaternary loess.

The oldest rocks exposed at the surface in the quadrangle are middle Miocene flood-basalt flows of the Grande Ronde Basalt, part of the Columbia River Basalt Group (Tolan and others, 1989, 2009; Reidel and Tolan, 2013; Reidel and others, 2013). Evidence from surrounding areas indicates that Paleogene and early Neogene volcanic and sedimentary rocks formed a terrain of low relief prior to inundation by the voluminous Grande Ronde flows (Beeson and others, 1989). The lavas erupted from fissures in eastern Washington and Oregon and western Idaho, traversed the Cascade Range by way of a broad structural lowland, and spread out to cover large areas of the Coast Range province (Swanson and others, 1979; Beeson and others, 1989; Wells and others, 2009). In the map area, Grande Ronde Basalt underlies most of the highlands west of the Columbia River floodplain and is present in the subsurface beneath it. After Grande Ronde eruptions ceased, fluvial deposits of ancestral Columbia River provenance accumulated atop the flows within and near the subsiding Portland Basin (Evarts and others, 2009a). Remnants of these deposits form a dissected sand and gravel bench north of McCarthy Creek along the west edge of the quadrangle.

The Quaternary period was likely a time of repeated incision and filling of the Columbia River valley owing to eustatic sea-level fall and rise during alternating glacial and interglacial periods. An extensive gravel fill, forming terraces at Oak Island and in the northwestern part of the map area, resulted from valley aggradation prior to the last glacial period.

In latest Pleistocene time near the end of the last glacial period, colossal outburst floods from Glacial Lake Missoula in western Montana inundated the Portland Basin. In the map area these floods were primarily erosive, but fine-grained flood deposits are present near the northwest corner of the quadrangle. 
Inset into the Pleistocene and older deposits are as much as $70 \mathrm{~m}$ of uppermost Pleistocene and Holocene sand, silt, and clay deposited by the Columbia and Willamette Rivers and their tributaries during the last 16,000 years as sea level rose from its last-glacial lowstand. During this period of floodplain aggradation, easterly winds entrained sandy floodplain sediment, creating now-stable dunes in the southwestern part of the map area.

The relatively mild and wet climate that prevailed in the western Pacific Northwest throughout most of the Cenozoic era (Wolfe and Hopkins, 1967; Wolfe, 1978) promoted intense chemical weathering and development of saprolitic soil horizons, locally as thick as $10 \mathrm{~m}$, on the older Neogene deposits. Natural bedrock outcrops are rare in the map area except at elevations below 200 ft (65 m) adjacent to the floodplain where the cataclysmic floods scoured surfaces. Elsewhere, exposures are limited to roadcuts, railroad cuts, and rock pits.

\section{Paleogene Sedimentary Rocks}

Sedimentary rocks assigned to the shallow-marine late Oligocene to early Miocene Scappoose Formation of Warren and Norbisrath (1946) (Tsf), which underlie the terrain in the Dixie Mountain quadrangle directly to the west (Madin and Niewendorp, 2008), presumably lie beneath the Grande Ronde Basalt in the shallow subsurface of the map area, but the only exposure (too small to show at map scale) of these sedimentary rocks is in a roadcut along U.S. Route 30 near Rocky Point, Oreg. Here, a flow of the informal Ortley member of Reidel and Tolan (2013) of the Grande Ronde Basalt invades a $>6$-m-thick section of well-bedded sandstone, siltstone, carbonaceous claystone, and lignite. The invasive flow warped bedding and baked some beds to a glassy, obsidianlike rock. The contact is marked locally by pillow lava or by mixed basalt-sediment breccia. The sandstone beds consist of angular grains of plagioclase, pyroxene, and oxide grains, lithic clasts, and foraminifera but contain little or no quartz or mica, all of which indicate an ancestral Cascade volcanic-arc provenance.

We tentatively assign these sedimentary rocks to the Scappoose Formation of Warren and Norbisrath (1946), but they could be younger deposits that are equivalent to similar strata invaded by Grande Ronde Basalt at Woodland, Wash., that Evarts (2004c) assigns to the Sandy River Mudstone.

\section{Columbia River Basalt Group}

In Miocene time, between 16.5 and $6 \mathrm{Ma}$, huge volumes of tholeiitic flood basalt erupted from fissures in southeastern Washington and adjacent Oregon and Idaho, forming the Columbia River Basalt Group. Some of the largest flows crossed the Cascade Range through a broad lowland and ultimately reached the Pacific Ocean (Beeson and others, 1979; Pfaff and Beeson, 1989; Beeson and others, 1989; Wells and others, 1989, 2009). West of the Cascade Range, thick sequences of lava flows buried large parts of low-relief terrain in the areas of the present-day Coast Range and Willamette Valley. ${ }^{40} \mathrm{Ar} /{ }^{39} \mathrm{Ar}$ ages indicate that most of the flood-basalt flows erupted during a brief period between 16 and $15 \mathrm{Ma}$ (Barry and others, 2010, 2013; Baksi, 2013), and they constitute the voluminous Grande Ronde Basalt and Wanapum Basalt (Beeson and others, 1989; Tolan and others, 1989, 2009; Reidel and others, 1989, 2013; Reidel and Tolan, 2013). These flows are medium-potassium tholeiitic basaltic andesite, distinguished from other Columbia River Basalt Group formations by their relatively high $\mathrm{SiO}_{2}$ and low $\mathrm{TiO}_{2}$ contents (Swanson and others, 1979; Mangan and others, 1986; Beeson and others, 1989; Reidel and others, 1989; Hooper, 2000). Well logs indicate that the Grande Ronde Basalt in the map area exceeds $200 \mathrm{~m}$ in thickness.

Reidel and Tolan (2013) divided the Grande Ronde Basalt on the Columbia Plain into 25 formal and informal members using lithologic, chemical, paleomagnetic, and stratigraphic criteria (fig. 2). 


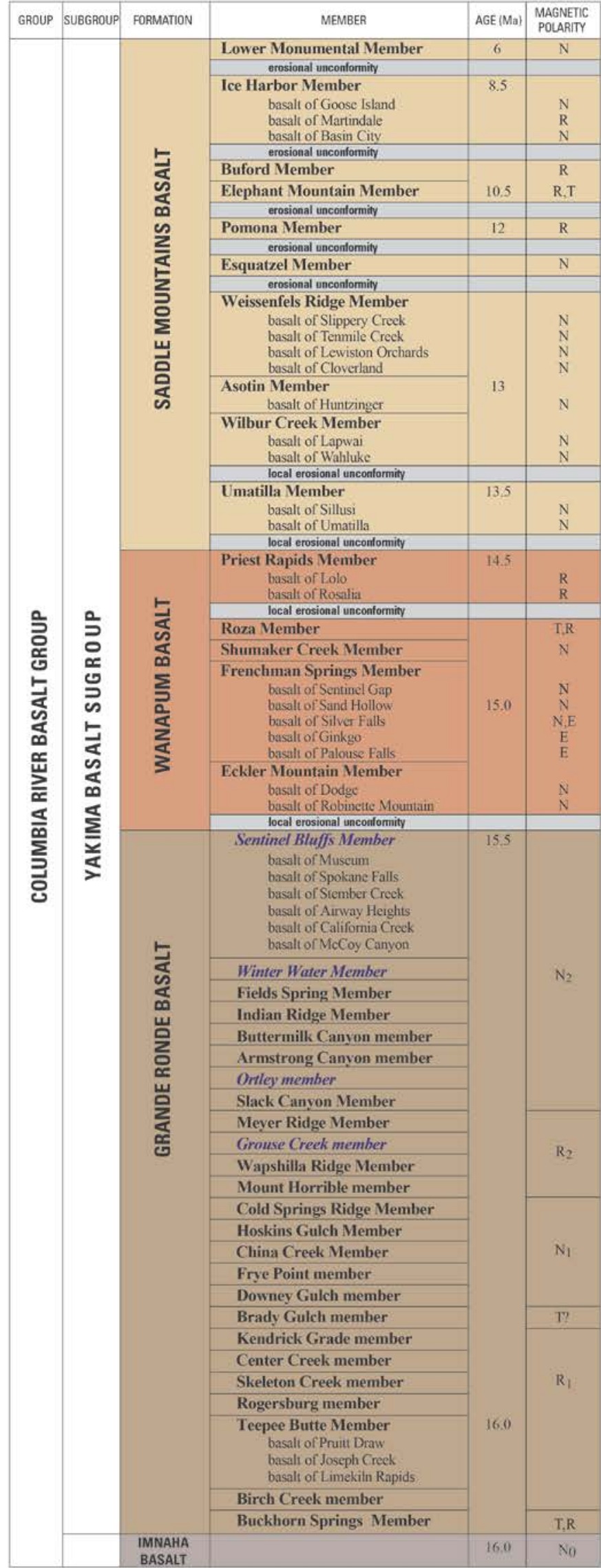

Figure 2. Stratigraphic nomenclature, ages, and magnetic polarities of the Columbia River Basalt Group, modified from Reidel (2005), Reidel and others (2013), and Reidel and Tolan (2013). For the Grande Ronde Basalt, formal members of Reidel and Tolan (2013) designated by upper case $M$, informal members designated by lower case $\mathrm{m}$. Magnetic polarity abbreviations: $\mathrm{N}$, normal; $\mathrm{R}$, reversed; $\mathrm{T}$, transitional; $E$, excursional; subscripts refer to magnetostratigraphic units of Swanson and others (1979). Units mapped in Sauvie Island quadrangle are shown in blue italics. 
Beeson and others (1989) and Wells and others (1989, 2009) traced some of these members into the Portland Basin and westward into the Coast Range. Lithological characteristics and chemical and laboratory paleomagnetic data from outcrops in the Sauvie Island quadrangle indicate that the flows here correspond to the upper part of the Grande Ronde Basalt and that they belong to four of the members defined by Reidel and Tolan (2013). These members are within the $\mathrm{R}_{2}$ and $\mathrm{N}_{2}$ magnetostratigraphic zones of Swanson and others (1979).

\section{Analytical Issues}

Assignment of Grande Ronde flows to Reidel and Tolan's (2013) members requires precise chemical analyses to detect the subtle compositional differences between units. Complicating assessments are interlaboratory bias and weathering effects. To eliminate potential analytical bias, most analyses reported here (table 1) were determined at the Peter Hooper GeoAnalytical Laboratory at Washington State University, using common instrumentation and standards. A few samples were analyzed at Franklin and Marshall College. Comparison with analyses of the same samples performed at both laboratories show consistent differences for some key elements such as Fe, P, Cr, and Zr, demonstrating the existence of interlaboratory bias. Consequently, data from the two laboratories are not directly comparable for detailed correlation purposes.

A greater difficulty in making correlations among Grande Ronde flows is accounting for the effects of chemical weathering, which can sufficiently modify rock chemistry to produce erroneous member assignments (Wells and others, 2009). Consequently, we rely mainly on analyses that meet two criteria related to extent of weathering. The first criterion is the degree of hydration, as recorded by losson-ignition values or by anhydrous totals. Samples for which loss-on-ignition values exceed 2.0 weight percent, or for which anhydrous totals are less than 98 weight percent, we judge likely affected by weathering. The second criterion is total Fe, calculated as $\mathrm{FeO}\left(\mathrm{FeO}^{*}\right.$ ) for normalized analyses (Wells and others, 2009). Most fresh Grande Ronde flows contain at least 11 weight percent FeO* (see Hooper, 2000; Reidel and Tolan, 2013). Many analyses of Grande Ronde flows in the Sauvie Island quadrangle and elsewhere in the Washington and Oregon Coast Ranges contain much less FeO*, some less than 8 weight percent (table 1). This is true even for some samples that have anhydrous totals above 98 weight percent and for samples that appear fresh in hand sample and thin section. We interpret the reduction in $\mathrm{FeO}^{*}$ content to reflect long-duration chemical weathering that can affect many elements, such as $\mathrm{MgO}$, $\mathrm{TiO}_{2}$, and $\mathrm{P}_{2} \mathrm{O}_{5}$, which are used to help distinguish Grande Ronde Basalt members. Therefore, we consider analyses that have loss-on-ignition values greater than 2.0 weight percent, anhydrous totals less than 98 weight percent, or $\mathrm{FeO} *$ contents less than 11 weight percent to be potentially affected by weathering, and, thus, we do not rely on these data for member assignments; these problematic analyses are noted in table 1 and indicated on figure 3. Note that unit assignments shown therein for problematic samples are provisional, inferred from evaluating the likely effects of weathering, as well as lithologic features, stratigraphic position, and paleomagnetic data. 

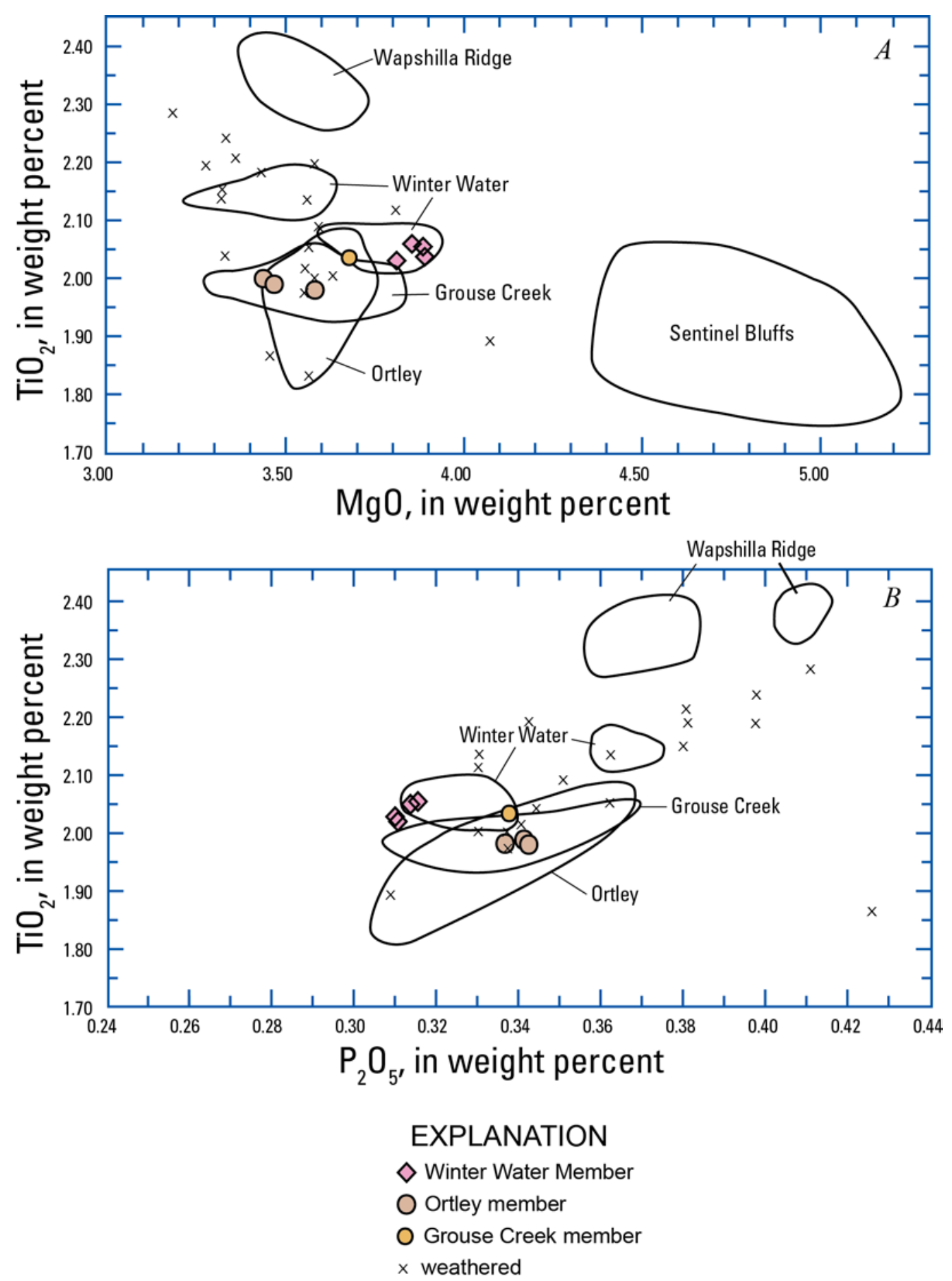

Figure 3. Chemical characteristics of Grande Ronde Basalt flows in Sauvie Island quadrangle. $A, \mathrm{MgO}$ versus $\mathrm{TiO}_{2}$ contents; $B, \mathrm{TiO}_{2}$ versus $\mathrm{P}_{2} \mathrm{O}_{5}$ contents. Black lines enclose compositional fields of members derived from analyses of Grande Ronde Basalt flows in western Columbia River Gorge (R.C. Evarts, unpub. data).

In most of the area mapped as Grande Ronde Basalt, only deeply weathered rock or loess are exposed at the surface, and the existence of basalt can be inferred only from well logs. All but one of the basalt samples that meet our weathering criteria (and that we consider reliable) are from roadcuts along U.S. Route 30. Depth of weathering is exemplified by analyzed samples from the Angell quarry near the south edge of the quadrangle, the only place in the map area exposing a significant thickness of Grande 
Ronde Basalt. Here, samples were collected at tens of meters below the original land surface, yet only one rock, collected from the deepest exposed level, is unweathered, according to our criteria. Laboratory paleomagnetic data were used to determine stratigraphic assignments in the quarry and elsewhere.

The Grande Ronde Basalt stratigraphy mapped in the Sauvie Island quadrangle is consistent with the log of a 705-ft (215 m)-deep water well (MULT 5) located along Skyline Boulevard about $1.5 \mathrm{~km}$ southwest of Rainbow Lake (available at http://or.water.usgs.gov/projs_dir/crbg/data/wells/mult__5/).

\section{Grande Ronde Basalt in the Sauvie Island Quadrangle}

The oldest Grande Ronde Basalt unit in the map area is assigned to the informal Grouse Creek (Tggc) member of Reidel and Tolan (2013). This member is exposed only in the Angell quarry near the south edge of the map area, where three flows crop out near the bottom of the pit. The 25-m-thick uppermost flow is too weathered for classification but has reversed magnetic polarity (table 2; fig. 4), indicating that it belongs to the $\mathrm{R}_{2}$ magnetostratigraphic unit. It directly underlies flows that have normal magnetic polarity, a position consistent with the Grouse Creek member regionally. The lower two flows, presumably also reversely magnetized, yielded fresh samples (table 1) that resemble Grouse Creek member flows elsewhere in western Oregon (Wells and others, 2009; R.E. Wells, unpub. data; R.C. Evarts, unpub. data). The composition of the lowest flow, which has low MgO (3.3 weight percent) and high $\mathrm{TiO}_{2}$ (2.14 weight percent) contents, is unusual for Grouse Creek member flows in western Oregon but does resemble a probable Grouse Creek flow mapped northwest of the Tualatin Valley, $30 \mathrm{~km}$ west of Sauvie Island (R.E. Wells, oral commun., 2013).

We assign two normally magnetized flows that overlie the reversely magnetized flows in the Angell quarry to the Ortley (Tgo) member of Reidel and Tolan (2013). Ortley member flows, also crop out along U.S. Route 30 and underlie the Rocky Point area. As in the Saint Helens quadrangle to the north (Evarts, 2004a), unweathered Ortley flows are distinguished from superjacent Winter Water Member flows by their lower $\mathrm{MgO}$ and $\mathrm{TiO}_{2}$ contents and their higher $\mathrm{P}_{2} \mathrm{O}_{5}$ contents (table 1, nos. 4,5), as well as by their steep north-to-northeast paleomagnetic direction (table 2; fig. 4). 


\section{EXPLANATION}

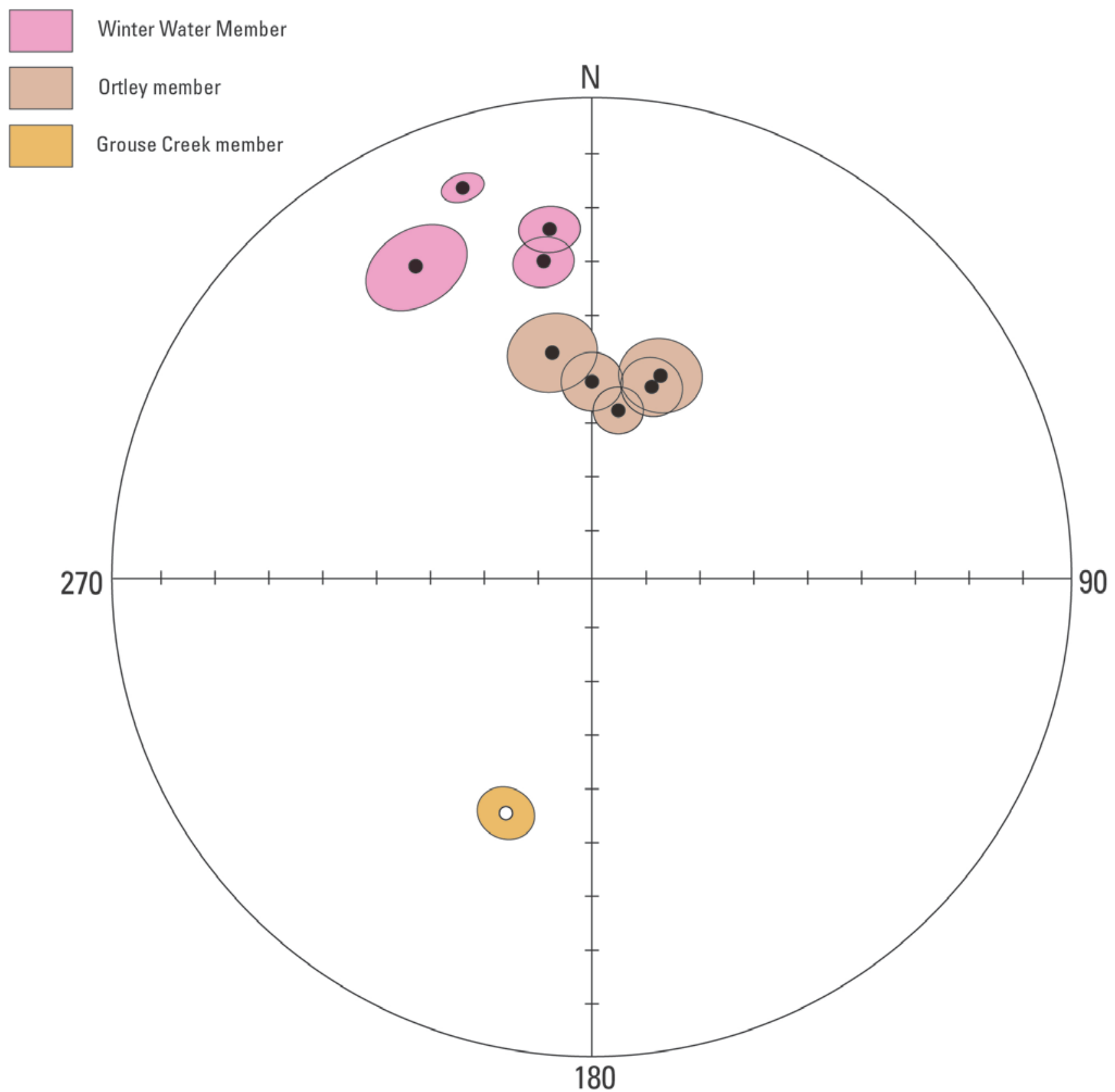

Figure 4. Paleomagnetic directions for Grande Ronde Basalt flows in Sauvie Island quadrangle. Dots show lower-hemisphere (normal) directions; open circles show upper-hemisphere (reversed) directions; thin lines outline areas of 95 percent confidence intervals.

In adjacent areas, the Ortley member is overlain by the Winter Water Member (Evarts, 2004a; Madin and Niewendorp, 2008; Madin and others, 2008). The Winter Water Member (Tgww) has lower $\mathrm{MgO}$ and higher $\mathrm{TiO}_{2}$ contents than the Sentinel Bluffs Member (Reidel and Tolan, 2013). Winter Water flows commonly contain scattered small phenocrysts and glomerocrysts of plagioclase, distinguishing it from most other Grande Ronde members (Reidel and others, 2013). Another diagnostic feature of some Winter Water Member flows is a shallow paleomagnetic inclination (table 2; fig. 4; Reidel and Tolan, 2013). The shallow inclination of sparsely phyric flows allows some weathered 
samples to be assigned to the Winter Water Member. The Winter Water Member crops out at the top of the Angell quarry and along stretches of nearby U.S. Route 30, and it is found in boreholes near the southern tip of Sauvie Island (M.H. Beeson, unpub. data). We infer that it underlies much of the upland area in the Sauvie Island quadrangle; however, its distribution west of McCarthy Creek is uncertain because of poor exposure, and parts of that area may be underlain by flows of the Ortley member or the Sentinel Bluffs Member. Two chemically distinct Winter Water Member flows have been identified in the western Columbia River Gorge (Wells and others, 2009). Both are probably present in the Sauvie Island quadrangle, but the compositions of all fresh Winter Water samples (table 1, nos. 15-18) correspond only to that of the uppermost flow in the gorge.

The youngest member mapped in the quadrangle is the Sentinel Bluffs Member (Tgsb), the uppermost member of the Grande Ronde Basalt on the Columbia Plateau. Although no outcrops of this unit are found in the map area, its presence is inferred from scattered exposures in adjacent areas (Evarts, 2004a; Madin and Niewendorp, 2008; Madin and others, 2008) where it is identified by its relatively high $\mathrm{MgO}$ contents and normal magnetic polarity.

\section{Neogene Sedimentary Rocks}

The Portland Basin probably began to form in early Miocene time, shortly before arrival of the Grande Ronde Basalt (Beeson and others, 1989; Beeson and Tolan, 1990; Evarts and others, 2009a). Fluvial and lacustrine sediments, supplied by the ancestral Columbia River and by tributaries that drain the surrounding highlands, filled the subsiding basin during the late Miocene and Pliocene. These deposits have been mapped from the Columbia River Gorge down the Columbia River to Kelso, $25 \mathrm{~km}$ north of the map area (Wilkinson and others, 1946; Lowry and Baldwin, 1952; Livingston, 1966; Trimble, 1957, 1963; Mundorff, 1964; Tolan and Beeson, 1984; Phillips, 1987a, b). Most workers assign these post-Grande Ronde Basalt nonmarine sedimentary strata to the Troutdale Formation of Hodge (1938). The Troutdale Formation in its type area near the west end of the Columbia River Gorge comprises three characteristic rock types: basalt-clast conglomerate, arkosic sandstone, and vitric sandstone. The conglomerate largely consists of well-rounded pebbles and cobbles of the Columbia River Basalt Group, but its most distinctive components are well-rounded, light-colored but commonly iron-stained pebbles of quartzite, granite, gneiss, and schist. These rock types, foreign to western Oregon and Washington, must have been transported from pre-Tertiary terranes east of the Cascade Range by the ancestral Columbia River. The arkosic sandstone largely consists of quartz, plagioclase, potassium feldspar, and felsic lithic clasts, and it contains minor but ubiquitous muscovite and biotite. Its components, like those of the interbedded conglomerate, are derived predominantly from sources in eastern Washington and Idaho. The vitric sandstone consists of sandy to pebbly, variably palagonitized hyaloclastic debris. Clasts in the vitric sandstone petrographically and chemically resemble lowpotassium tholeiite flows erupted from late Pliocene volcanic centers in the Cascade Range (Tolan and Beeson, 1984; Swanson, 1986; Evarts and others, 2009b).

Scattered outcrops and abundant subsurface data from water-well drillers’ logs show a conglomeratic section as much as 120 m thick overlying finer grained strata throughout most of the Portland Basin. Trimble (1957) and Mundorff (1964) divided the Troutdale Formation into informal upper and lower members on the basis of their pronounced grain-size differences. Trimble (1963) later formally named the lower fine-grained member the Sandy River Mudstone (Tsr).

Subsequent work, summarized in Evarts and others (2009a), shows that stratigraphic relations among the various basin-fill facies are more complex than previously envisioned. In particular, some unconsolidated to cemented, gravelly deposits, that were previously assigned to the Tertiary Troutdale Formation, instead probably record Pleistocene deposition. 


\section{Troutdale Formation}

Sediments deposited by the ancestral Columbia River (Ttfc) overlie the Columbia River Basalt Group in the Rainbow Lake area, forming benches as high as $250 \mathrm{ft}$ (75 m) above sea level. Well logs show that these benches are underlain by as much as $65 \mathrm{~m}$ of gravel and sand resting on basalt. The cemented nature of these deposits, as described in the logs, indicates that they must be older than Late Pleistocene. A temporary roadcut along NW Cornelius Pass Road near U.S. Route 30 exposed $10 \mathrm{~m}$ of bedded sand and gravel. Here the deposit is mostly sand but includes gravel beds as thick as $1.5 \mathrm{~m}$. The sand is quartzofeldspathic and contains abundant mica, indicating a Columbia River provenance. The gravel beds contain diverse lithologies, including clasts of the Columbia River Basalt Group and quartzite from upriver terranes. The uppermost several meters are strongly oxidized, and most nonmetamorphic clasts have completely decomposed.

Trimble (1963) tentatively mapped these benches as equivalent to fine-grained catastrophic-flood deposits, but we provisionally assign them to the Troutdale Formation. From well-log descriptions and the limited exposures, they seem likely to be equivalent to the informal conglomerate member of Evarts and others (2009a) and, hence, of assumed late Miocene or Pliocene age. Less likely is that these deposits are equivalent to the (younger) unnamed conglomerate unit (QTc).

\section{Quaternary Deposits}

\section{Deposits of the Columbia River Valley}

The major influences on sedimentation in the lower Columbia River valley during Quaternary time were glacially induced changes in sea level (Warne and Stanley, 1995), colossal floods (Bretz, 1925; Trimble, 1963; Allison, 1978; Zuffa and others, 2000; Benito and O’Connor, 2003; Evarts and others, 2009a), and eolian transport and reworking of fluvial deposits. It is also possible that volcanogenic and glacier-related aggradation and sediment transport on the Lewis River, which joins the Columbia River $12 \mathrm{~km}$ north of the map area, has occasionally affected Columbia River deposition in the map area by damming, and subsequently raising the level of, the Columbia River (Vogel, 2005; Evarts and others, 2009a).

Two main bodies of Quaternary deposits cover much of the map area to a depth of at least 230 to $300 \mathrm{ft}$ (70 to $90 \mathrm{~m}$ ) below sea level. A dominantly gravel conglomerate, which is mostly in the subsurface, crops out at Oak Island and in the northwest corner of the map area. It has been locally incised and filled with fine-grained alluvium from the Columbia and Willamette Rivers during sea-level fall and rise caused by Late Pleistocene glaciation. The surface of this fill constitutes the modern Columbia and Willamette River floodplain. Eolian deposits locally mantle upland areas and form large dunes and benches closer to river level.

\section{Unnamed Conglomerate}

A weakly to moderately consolidated, cobbly conglomerate (QTC) underlies Oak Island and

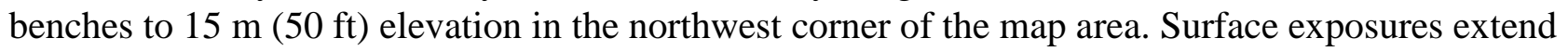
north of the map area to $6 \mathrm{~km}$ north-northeast from Scappoose as a prominent terrace along the Columbia River floodplain (fig. 5). The deposit is poorly exposed in the map area but appears in several large gravel pits near Scappoose. Pit faces as much as $15 \mathrm{~m}$ high show subhorizontal layers 0.5 to $2 \mathrm{~m}$ thick of clast-supported round-cobble gravel that has a compact to loose, sandy matrix. Cobbles consist of diverse lithologies, including many Columbia River Basalt Group units and less-abundant hornblende andesite, olivine basalt, quartzite, and granitic rocks. The quartzite and granitic clasts are derived from Columbia River sources from east of the Cascade Range. Layers, which locally contain sets of north- 
dipping tabular foresets, are, in places, separated by horizontal sand lenses as thick as $30 \mathrm{~cm}$ composed of micaceous quartzofeldspathic sand. Some gravel layers are partly cemented, apparently by iron oxides or silica. Sedimentary structures and composition indicate deposition by the north-flowing Columbia River during a time of substantial gravel transport.

Well logs indicate that the unnamed conglomerate on Oak Island extends into the subsurface, forming a subsurface gravel bench that underlies fine-grained Pleistocene and Holocene fill beneath Multnomah Channel and the Columbia River (fig. 5 cross section $A-A^{\prime}$ ). To the north, the gravel also is contiguous with subsurface benches in the northwest corner of the map area. Few wells penetrate the gravel, but the driller's log for MULT 4217 at the south tip of Sauvie Island shows the gravel from 191 to $258 \mathrm{ft}$ (58 to $79 \mathrm{~m}$ ) below sea level. Similarly, the log for MULT 51366 on the east bank of the Willamette River along the south edge of the map area shows gravel from $166 \mathrm{ft}$ (51 m) to more than $301 \mathrm{ft}$ (92 m) below sea level, indicating that the gravel locally exceeds a thickness of $41 \mathrm{~m}$.

The age of deposition is uncertain. The terrace surface near Scappoose is oxidized to a depth of 2 $\mathrm{m}$, and many fine-grained volcanic clasts in the oxidized zone have weathering rinds of 2 to $6 \mathrm{~mm}$, rare clasts having rinds as thick as $1 \mathrm{~cm}$. Such degrees of soil development and rind thicknesses (as well as overlying cataclysmic-flood deposits outside the map area) indicate a Quaternary age but probably predating the Last Glacial Maximum associated with Oxygen Isotope Stage 2 (25-11 ka). Preliminary, divergent luminescence age estimates (table 3) from quarries near Scappoose indicate a late Quaternary age of 80 to $15 \mathrm{ka}$ for the uppermost $8 \mathrm{~m}$ of this gravel. Gravel at depth may be substantially older. Cobbles in a 1-m-thick excavation on Oak Island had thinner weathering rinds 0.5 to $1 \mathrm{~mm}$ thick, perhaps because the cataclysmic floods eroded some of these gravel deposits.

The distribution, thickness, sedimentology, and age of the unnamed conglomerate indicates that it was deposited by earlier episodes of Columbia River valley filling, similar to the valley filling in Late Pleistocene and Holocene time in response to sea-level rise but during times of more gravel transport. The uneven surface of the gravel may consist of multiple terraces produced by several periods of aggradation and incision, by erosion by the cataclysmic floods or last-glacial valley incision, or by tectonic deformation.

\section{Cataclysmic Flood Deposits}

During the late Pleistocene Last Glacial Maximum, an ice dam impounded Glacial Lake Missoula in western Montana. The dam failed repeatedly (Waitt, 1980, 1985), releasing floods that coursed down the Columbia River and into the Portland Basin (Bretz, 1925, 1959; Bretz and others, 1956; Trimble, 1963; Allison, 1978; Waitt, 1996; Benito and O’Connor, 2003; Evarts and others, 2009a). A narrow Columbia River valley downstream of Sauvie Island helped cause temporary ponding in the Portland Basin and tributary valleys to as high as $400 \mathrm{ft}$ (120 m) (Allison, 1978; O’Connor and others, 2001; Minervini and others, 2003). This ponding caused deposition of as much as $20 \mathrm{~m}$ of finegrained sediment throughout the Portland area (O’Connor and others, 2001; Evarts, 2004b).

Outside of the Sauvie Island quadrangle where they are thick and well exposed, cataclysmicflood slack-water accumulations show multiple 0.25- to 1.5-m-thick, fining-upward sequences of ripple cross-stratified fine sand that grades up to massive, bioturbated clayey silt. Most fining-upward sequences were deposited by individual floods (Glenn, 1965; Waitt, 1980, 1985). The sandy horizons are composed of quartz, feldspar, basalt fragments, and conspicuous mica, indicative of a Columbia River provenance. This slack-water facies of cataclysmic-flood deposits is regionally correlative to Trimble’s (1963) “sandy” and “silty and clayey” phases of Quaternary “lacustrine deposits.”

The floods also left coarse-grained deposits in the form of large bars or delta complexes, particularly in the eastern Portland Basin where the constricted Columbia River valley at the western end of the Columbia River Gorge forced high flow velocities (Benito and O’Connor, 2003; Evarts and 
others, 2009a). Similar, but smaller, areas of coarse-grained cataclysmic-flood deposits are found north of the map area downstream of the Columbia River valley constriction near Saint Helens, Oreg. In the Portland Basin, the coarse-grained cataclysmic-flood deposits broadly correspond with Trimble's (1963) "gravelly phase" of Quaternary "lacustrine deposits." Coarse-grained facies of the cataclysmic-flood deposits are not mapped at the surface of the Sauvie Island quadrangle, but they may be present in the subsurface where they are not distinguishable from the unnamed conglomerate (QTc) in drillers' logs.

Radiocarbon ages, paleomagnetic measurements, and tephrochronologic data indicate that the last-glacial episode of flooding was between about 20 and 15 ka (Waitt, 1985, 1994; Atwater, 1986; Clague and others, 2003; Benito and O’Connor, 2003; O’Connor and Benito, 2009). Similar episodes of cataclysmic flooding probably occurred earlier in the Quaternary (McDonald and Busacca, 1988; Zuffa and others, 2000; Bjornstad and others, 2001; Pluhar and others, 2006), but deposits from them have yet to be recognized in the Portland Basin.

Mapped cataclysmic-flood deposits are sparse in the Sauvie Island quadrangle. The only substantial accumulations are small benches of fine-grained deposits (Qfs) that abut the eastern margin of the Tualatin Mountains at the west edge of the map area. It is probable that many small deposits thinly and discontinuously mantle the upland areas and terraces west of the modern floodplain as much as $400 \mathrm{ft}(120 \mathrm{~m})$ above sea level. Coarse-grained deposits that are indistinguishable in well logs from the unnamed conglomerate likely lie in the shallow subsurface. 


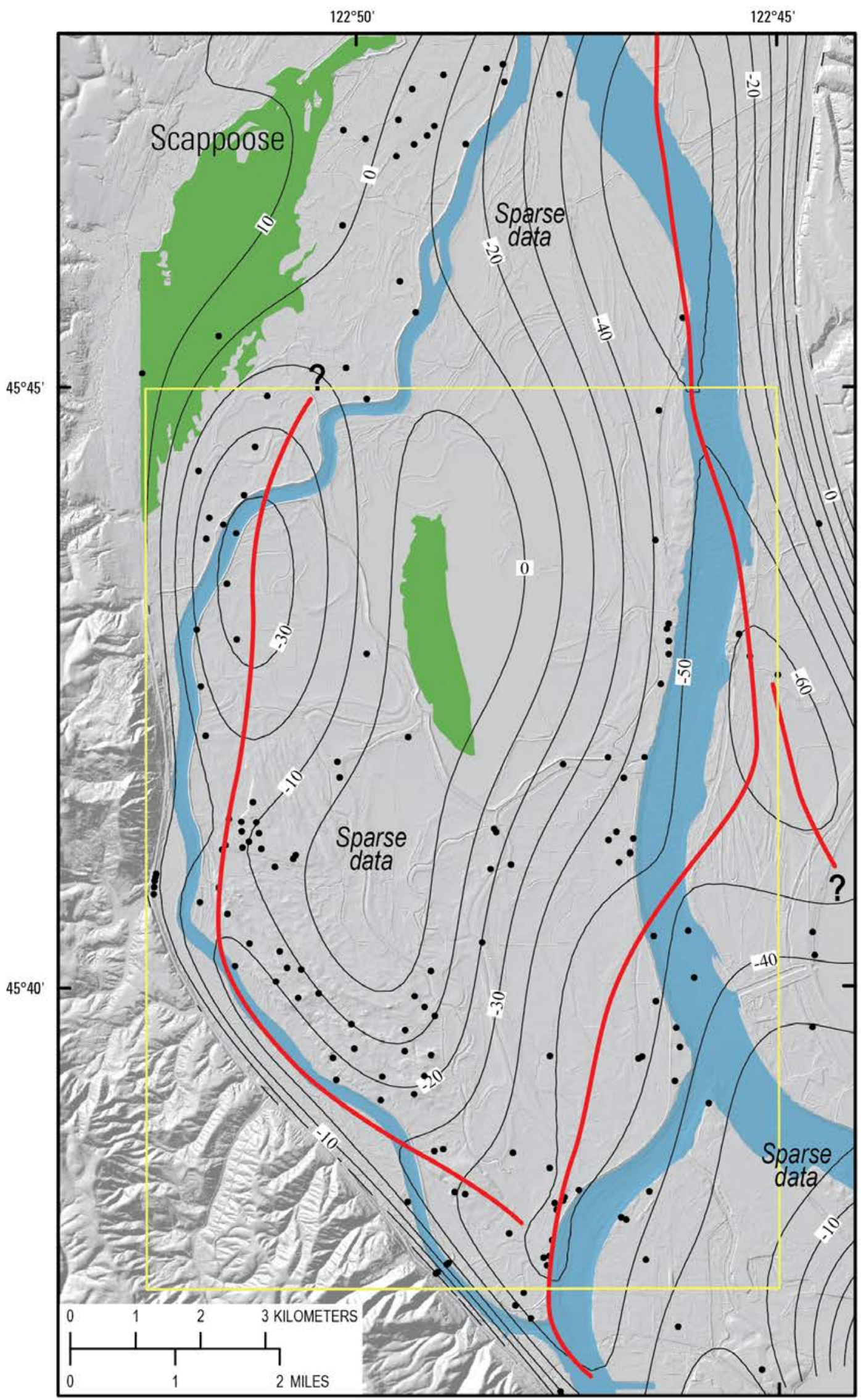

Shaded relief image derived from Lidar data ortained from U.S. Army Corps of Engineers and the Oregon Lidar Consortium
Figure 5. Estimated elevation (in meters) of top of the unnamed conglomerate (QTC) in Sauvie Island quadrangle (yellow outline) and adjacent areas. Contours constructed by fitting a tenth-order global polynomial to gravellayer elevations recorded in logs of water wells and geotechnical wells (black dots), as well as mapped extent of unnamed conglomerate (green areas). Well locations not field located but estimated from provided location information provided and tax-lot data. In places, particularly southwestern part of map area, gravel may be coarse-grained cataclysmic flood deposits rather than the (older) unnamed conglomerate. Red lines show inferred axes of late Pleistocene Columbia and Willamette River channels; queried where location uncertain. 


\section{Holocene Alluvial Deposits}

Holocene and Late Pleistocene Columbia River and Willamette River floodplain deposits largely comprise sand, silt, clay, and local concentrations of organic debris. Quartz, feldspar, and lithic fragments dominate the sand. The quartz, as well as conspicuous muscovite, derives from pre-Tertiary nonvolcanic terranes east of the Cascade Range. Many lithic fragments, particularly in coarse sand size, are from rocks of the Cascade Range (Whetten and others, 1969; Gates, 1994). This sediment occupies incised Willamette and Columbia River valleys that were cut during glacial periods of low sea level and then filled as sea level rose after 16 ka (Baker and others, 2010; Peterson and others, 2011). Deposition likely kept pace with rising sea level, producing a fill mainly of channel and floodplain deposits. The fill is deepest in the ancestral Columbia and Willamette River channels, which closely correspond to the present channel locations, including Multnomah Channel (fig. 4). Drillers' logs and boreholes indicate that the deepest fill extends to a depth of 210 to $230 \mathrm{ft}$ (65 to $70 \mathrm{~m}$ ) below sea level. Similar fills at similar depths are found in boreholes $4 \mathrm{~km}$ east of the map area near the Interstate Route 5 bridge (Peterson and others, 2011). These observations resemble those found near the mouth of the Willamette River, where high-resolution seismic-reflection surveys led Pratt and others (2001) to infer two paleochannels (perhaps corresponding to the ancestral Willamette and Columbia Rivers) at depths of $\sim 60$ and $80 \mathrm{~m}$ below sea level.

Radiocarbon dates from boreholes in the Portland Basin and at the mouth of the Columbia River indicate that the rate of floodplain aggradation was about $1.5 \mathrm{~cm} / \mathrm{yr}$ during rapid sea-level rise between 11 and $9 \mathrm{ka}$, but slowed to about $0.3 \mathrm{~cm} / \mathrm{yr}$ since 9 ka (Baker and others, 2010; Peterson and others, 2011). Floodplain deposits above low water level in the map area (Columbia River datum, which is about $5 \mathrm{ft}$ ( $1.4 \mathrm{~m}$ ) elevation (NAVD88) are typically younger than 2 to 3 ka (Evarts and others, 2009a; table 4).

Holocene floodplain deposits reach as high as $30 \mathrm{ft}(9 \mathrm{~m})$ in the map area. This elevation reflects the limits of Columbia River flooding; the maximum historical (1894) flood on the Columbia River reached a stage of $38 \mathrm{ft}(11.5 \mathrm{~m})$ above sea level at the Willamette River confluence (U.S. Army Corps of Engineers, 1968).

We separate the Holocene and Pleistocene Columbia River and Willamette River floodplain deposits into a coarser sand facies and a finer silt and clay facies. The sand facies (Qcwc), mostly sand and silt, forms (1) distinct ridge-and-swale topography along the Columbia River and Multnomah Channel, and (2) higher deposits in major and minor floodplain channels. The sand facies generally forms the higher floodplain surfaces 20 to $30 \mathrm{ft}$ (6 to $9 \mathrm{~m}$ ) above sea level. The ridge-and-swale topography consists of en echelon point bars or natural levees caused by lateral channel movement of the Columbia River and secondary channels like Multnomah Channel. Exposures outside of the map area show locally stratified, fine-to-medium sand in layers as thick as $30 \mathrm{~cm}$ (probably from individual floods), alternating with silty sand (J.E. O’Connor, unpub. data). Subhorizontal and inclined bedding attitudes indicate deposition by vertical and lateral accretion. Higher sandy deposits along meandering floodplain channels form natural levees and crevasse splays, which were deposited when there was concentrated water- and sediment-transport between main channels and low flood basins during floods. The natural levees and bird-foot delta formed by the Gilbert River progradation into Sturgeon Lake is a prominent example.

The silt and clay facies (Qcwf) includes silt, clay, and minor sand in low parts of the Columbia River floodplain, typically at elevations below $3 \mathrm{~m}(10 \mathrm{ft})$ above sea level. These deposits underlie drained lake beds on Sauvie Island and are likely the substrate of existing lakes like Sturgeon Lake. Bank exposures, auguring, and trenches show silt, clay, and organic material in horizontal laminae typically 0.1 to $2 \mathrm{~cm}$ thick, reflecting thin deposition from overbank floods that invaded floodplain marshes, ponds, and lakes. 
Subsurface data are sparse, but the silt and clay facies appears to dominate except near the Columbia River and Multnomah Channel (cross sections $A-A^{\prime}$ and $B-B^{\prime}$ ). These places appear to be persistent locations of the major channels during Holocene valley aggradation. Drillers' logs commonly report organic detritus within finer deposits in the subsurface. The abundance of sand-facies deposits on the surface of the present floodplain may reflect sea level stability during the last 2,000 years, allowing progradation of sand across the floodplain surface during channel migration and growth of natural levees and crevasse splays.

The floodplain has been modified by construction of levees, deposition of dredge spoils, and filling to raise the surface elevation above flood stages. These areas are mapped as artificial fill (af). The largest areas of artificial fill are the port facilities that flank the Willamette and Columbia Rivers near the southeast corner of the map area, where fill has raised the surface elevation to above $30 \mathrm{ft}(9 \mathrm{~m})$ in many areas. Fill along the Columbia River banks consists mainly of medium to coarse sand dredged from the shipping channel.

\section{Loess}

As much as several meters of massive, light-brown micaceous silt (Qlo) covers most of the upland ridges. This deposit is quartzofeldspathic, similar to the fine facies of the catastrophic flood deposits but at higher elevations. Because it resembles some beds in the Troutdale Formation, it was considered an upper silty phase of the Troutdale by Lowry and Baldwin (1952), who named it the Portland Hills Silt Member of the Troutdale Formation. Lentz (1981) showed it to be loess composed of material blown from the Columbia River floodplain during Pleistocene glacial episodes.

Luminescence ages from loess deposits in the Tualatin Mountains south of the map area range from 39 to more than $79 \mathrm{ka}$ (table 3). These loess deposits are geochemically and sedimentologically similar to the thick loess accumulations of the Palouse Hills of eastern Washington (Lawes, 1997), which have been accumulating since at least $900 \mathrm{ka}$ (Busacca, 1991). Some loess in upland areas may have accumulated during the Holocene, as documented by Punke and others (2011) for an archeological site near Ridgefield, east of the map area. The micaceous silt is widespread, but we map loess only where it thickly mantles low-relief surfaces at higher elevations.

\section{Eolian Deposits}

Undulating hills of massive fine sand and silt (Qe) dominate southwestern Sauvie Island. Similar deposits underlie low benches at the base of the Tualatin Mountains west of Multnomah Channel. They are composed of quartzofeldspathic sand and silt containing common muscovite and minor lithic fragments (Ruzek and Carpenter, 1922). These hills and benches are inferred to be stabilized dunes and benches of wind-blown sediment. The deposits are as high as $79 \mathrm{ft}(24 \mathrm{~m})$ above sea level, well above the range of historical flooding. They were preferred sites for early settlement of Sauvie Island before dike development and flow regulation.

The eolian landforms do not appear to be active. As much as $2 \mathrm{~m}$ of oxidized surface soils on the Sauvie Island dunes indicate stability for hundreds or thousands of years. Well logs show that sand under the Sauvie Island dunes generally extends down to a depth of 30 to $60 \mathrm{ft}$ (10 to $20 \mathrm{~m}$ ) below sea level, and they can be locally as deep as $90 \mathrm{ft}(30 \mathrm{~m})$. The dunes may have begun forming as long as 9,000 years ago during lowered sea levels, as documented by dated Holocene floodplain deposits at similar depths along the lower Willamette River (Peterson and others, 2011). Distinguishing eolian sediment from floodplain sediment in drillers' logs is difficult, and so the subsurface extent of eolian sediment is uncertain.

The dunes and benches likely were formed by southeasterly winds that entrained Columbia and Willamette River beach and bar sands exposed during periods of low water. 


\section{Landslide Deposits}

Landslides are widespread in the upland areas of the Sauvie Island quadrangle and in areas to the west and south (Madin and Niewendorp, 2008; Madin and others, 2008). Mapped landslide deposits (QIs) are largely from deep-seated landslides resulting from failure of deeply weathered bedrock or of thick, clay-rich soils derived from basalt. Most probably were triggered by intense rainfall, undercutting of steep creekbanks, or seismic shaking. Some landslides blocked drainages and caused upstream accumulation of tributary alluvium.

\section{Structural Features}

A pronounced topographic escarpment across the southwestern part of the Sauvie Island quadrangle defines the southwest margin of the shallow, but structurally complex, Neogene Portland Basin (Evarts and others, 2009a). Grande Ronde Basalt flows that underlie the uplands southwest of the margin have been deformed into the asymmetric, northwest-trending Tualatin Mountains Anticline. The northeast limb of the anticline is well exposed in the large Angell quarry, but, elsewhere in the map area, structure is poorly constrained by limited outcrop exposures. Faults related to the basin boundary are inferred to underlie the Columbia River floodplain largely on the basis of data from outside of the map area.

\section{Tualatin Mountains Anticline}

The flood-basalt flows of the Columbia River Basalt Group are widespread units that had nearhorizontal surfaces and, thus, constitute excellent marker beds for detecting deformation since $15 \mathrm{Ma}$ (Beeson and Tolan, 1990). The surfaces of the basalt flows that underlie the southwestern part of the map area strike northwest and dip northeast, forming the northeast limb of the faulted, asymmetric Tualatin Mountains Anticline (Trimble, 1963; Balsillie and Benson, 1971; Beeson and others, 1985, 1989, 1991; Beeson and Tolan, 1990; Madin and others, 2008). Where exposed in the Angell quarry and nearby roadcuts, Grande Ronde Basalt flows increase in dip from subhorizontal near the ridgecrest to $11^{\circ}$ to $13^{\circ}$ along U.S. Route 30. Borehole logs at the Sauvie Island Bridge (M.H. Beeson, unpub. data, 2003) indicate that the Grande Ronde Basalt flows dip $10^{\circ}$ to $18^{\circ}$ in the subsurface beneath Multnomah Channel. The axis of the Tualatin Mountains Anticline is projected from the south (Madin and others, 2008) to pass near the intersection of Cornelius Pass Road and Sheltered Nook Road, where columnar jointing suggests that a Winter Water Member flow there is subhorizontal. However, the crest of the anticline appears to be quite broad, and the location of its axis is poorly constrained by limited outcrop. The Winter Water Member is present at a lower topographic level in McCarthy Creek than it is to the southeast, implying either that the fold axis plunges to the northwest or that offset exists on unmapped faults.

A parallel shallow syncline, its limbs dipping 2 to $3^{\circ}$, was mapped to the north (Evarts, 2004a). The buried extension of this structure is inferred to transect the northeastern part of the Sauvie Island quadrangle.

\section{Portland Hills Fault Zone}

Geologists have long speculated that the abrupt, linear, northeast-facing front of the Tualatin Mountains is the geomorphic expression of a major structure, the Portland Hills Fault (Treasher, 1942; Dehlinger and others, 1963; Newton, 1969; Balsillie and Benson, 1971; Beeson and others, 1985, 1991; Madin, 1990; Yelin and Patton, 1991). Some have interpreted the Portland Hills Fault as one element in a northwest-trending zone of structural disruption, commonly called the Portland Hill Fault Zone, that 
extends 60 km to the lower Clackamas River (Schlicker and Deacon, 1967; Schmela and Palmer, 1972; Beeson and others, 1985, 1989, 1991; Blakely and others, 1995, 2000, 2004; Wong and others, 2001).

\section{Portland Hills Fault}

Despite the pronounced topographic break, evidence indicating the location, orientation, magnitude, sense of slip, age, and even existence of a fault at the base of the Tualatin Mountains front remains elusive. Madin and others (2008) mapped the Portland Hills Fault at the topographic break in the adjacent Linnton quadrangle but noted "The exact location of the trace, the dip, and the sense of slip of the Portland Hills Fault are unknown." The fault has been variously interpreted as a northeast-dipping normal fault (Balsillie and Benson, 1971; Beeson and others, 1991), a dextral oblique-slip wrench fault (Beeson and others, 1985, 1989, 1991; Beeson and Tolan, 1990), and a southwest-dipping reverse fault (Blakely and others, 1995; Wong and others, 2001). Balsillie and Benson (1971) postulated that the top of the Columbia River Basalt Group was dip-slip offset $230 \mathrm{~m}$ across the fault and suggested that the northeast dip of the Columbia River Basalt flows in the upland area resulted from drag against the normal fault. In the Angell quarry, however, it is clear that the northeast dips of Grande Ronde Basalt flows reflect regional folding rather than local warping. Furthermore, use of the top of the Columbia River Basalt Group as a datum fails to consider differential erosion. Data from boreholes at the Sauvie Island Bridge (M.H. Beeson, affiliation, unpub. data, 2003) show that Winter Water Member flows continue from outcrops along U.S. Route 30 into the subsurface beneath Multnomah Channel and that no significant vertical displacement is required. The drill cores do show local evidence of tectonic disruption and subhorizontal slickensides suggestive of strike-slip motion, which is consistent with the linearity of the mountain front and with the right-lateral offsets documented for other northwest-striking faults in the Portland region (Blakely and others, 2000).

From high-resolution aeromagnetic data, Blakely and others (1995) constructed an interpretative profile about $8 \mathrm{~km}$ southeast of the map area. They model the Portland Hills Fault as a high-angle, southwest-dipping reverse fault that has modestly $(<100 \mathrm{~m})$ offset the top of the Columbia River Basalt Group; however, whether or not the top of the basalt represents the same stratigraphic horizon on both sides of the fault is unknown.

The Portland Hills Fault projects northwestward through the Rainbow Lake area. North of the fault, flows of the Ortley member of the Grande Ronde Basalt dip basinward as they do to the south, but they display a more north-directed strike, suggesting clockwise rotation of a crustal block. In contrast, paleomagnetic declinations of Ortley member flows near Rocky Point are oriented counterclockwise relative to sites to the south. The reason for this apparent discrepancy is unclear, but both the structural and paleomagnetic data indicate that the areas north and south of the inferred fault trace belong to separate structural blocks.

\section{East Bank Fault}

In the Portland quadrangle, Beeson and others (1991) mapped a buried, west-side-down fault 2.5 km northeast of, and parallel to, the Portland Hills Fault. This structure, named the East Bank Fault by Blakely and others (1995), coincides with a linear array of aeromagnetic anomalies. The interpretative profile of Blakely and others (1995), about $8 \mathrm{~km}$ southeast of the map area, models the East Bank Fault as a steeply northeast-dipping reverse fault that has less than $200 \mathrm{~m}$ of vertical offset, consistent with constraints from nearby well logs. Madin and others (2008) extended the East Bank Fault into the northeastern part of the Linnton quadrangle. We extend it into the southern part of the Sauvie Island quadrangle, where it appears to terminate against a magnetic boundary that we infer to indicate a buried northeast-striking fault. 


\section{Other Faults}

Madin and others (2008) mapped the Portland Harbor Fault as lying between the Portland Hills and East Bank Faults and running beneath the Willamette River. Its existence is inferred from engineering borings indicating that the buried surface of the Columbia River Basalt Group drops down abruptly at least $50 \mathrm{~m}$ on the northeast side. The projection of this fault northward into the Sauvie Island quadrangle intersects the East Bank Fault just north of the map boundary.

Seismic-reflection surveys near the south boundary of the quadrangle attempted to locate faults showing evidence of Quaternary or Holocene offset. A survey directly south of the map area imaged possibly tectonic disruption of sediments beneath Multnomah Channel (Ryan and Stevenson, 1994). A high-resolution survey along the southeast shoreline of Sauvie Island (Pratt and others, 2001) detected two possible fault zones and a possible fault-related anticline within Late Pleistocene to Holocene sediment beneath the Willamette River. One of the inferred faults aligns with the projection of the East Bank Fault of Blakely and others (1995). Both seismically imaged faults step down to the east, consistent with subsidence of the Portland Basin but opposite to the sense of displacement on the East Bank Fault as interpreted by Blakely and others (1995).

Beeson and others (1991) mapped several northeast-striking transverse structures that segment the Tualatin Mountain Anticline in the Portland quadrangle to the southeast. Similar transverse faults may exist in the map area but remain undetected owing to poor exposure. The northeast-trending magnetic boundary that truncates the aeromagnetic lineament associated with the East Bank Fault may be such a transverse fault. Transverse faults also may account for the distribution of the Winter Water Member of the Grande Ronde Basalt as noted above.

\section{Summary}

Limited and conflicting data keep the nature of the structures that bound the southwestern Portland Basin enigmatic. The Portland Hill Fault Zone evidently consists of multiple subparallel structures that have varied displacements. The Portland Hills Fault appears to be mainly a strike-slip fault that has minimal vertical offset. Regional stress patterns inferred from geologic and geophysical data, as well as earthquake focal mechanisms and the Global Positioning System-derived velocity field, all suggest that motion likely is dextral (Blakely and others, 1995; Wells and others, 1998; Wong and others, 2001; McCaffrey and others, 2007). Dominantly strike-slip motion is consistent with the linear character of the topographic break but does not explain the escarpment. Neither can the buried East Bank Fault, which shows the opposite (basin side up) sense of offset. The escarpment may simply reflect control exerted by resistant Grande Ronde Basalt flows on the limb of the northwest-trending Tualatin Mountain Anticline. Given evidence for regional transpression (Blakely and others, 1995; Wong and others, 2001), the anticline could be a fault-propagation fold above a southwest-dipping blind thrust fault.

\section{Geologic Resources}

Geologic resources available in the Sauvie Island quadrangle are largely nonmetallic industrial materials. Intense weathering of Grande Ronde Basalt has produced residual ferruginous bauxite deposits at many locations to the west and north (Libbey and others, 1945), but no occurrences are recorded in the map area, nor have metallic deposits or significant hydrothermal alteration associated with such deposits been found. Coarse aggregate derived from Grande Ronde Basalt flows possesses desirable engineering properties for many construction uses. Several quarries have been developed in this unit in the map area (Gray and others, 1978), but only the large Angell quarry is active currently. Unconsolidated alluvial deposits of the Columbia River floodplain are potential sources for sand and 
gravel. Several gravel pits exploit the unnamed conglomerate (QTc) near Scappoose, north of the map area.

\section{Geologic Evolution}

The Portland Basin and its bounding structures have had a long and complex tectonic history. Beeson and Tolan $(1989,1990)$ suggested that the basin began to form in middle Miocene time, shortly before emplacement of the Grande Ronde Basalt. Evarts and others (2009a) suggested that this protobasin was a synclinal trough that probably formed during an early to middle Miocene compressional episode. This event also produced the northwest-trending Tualatin Mountains Anticline and corresponding folds throughout a broad region of western Oregon and Washington (Evarts and Swanson, 1994; Beeson and others, 1989; Beeson and Tolan, 1990). The middle Miocene pre-Grande Ronde landscape constituted a terrain of modest relief (150 to $180 \mathrm{~m}$ ) eroded into mildly deformed Paleogene volcanic and sedimentary rocks (Wilkinson and others, 1946; Beeson and others, 1989). Starting at about $16 \mathrm{Ma}$, flood-basalt flows of the Grande Ronde Basalt, which followed the ancestral Columbia River valley, entered the incipient Portland Basin and spread widely throughout the region. The ancestral Columbia River was displaced repeatedly by late Grande Ronde Basalt flows that eventually filled the valley and covered much of the adjacent, topographically subdued upland areas.

Although the timing and duration of deformation in the Sauvie Island quadrangle are unclear, the development of northwest-striking folds and associated faults, including the Portland Hills Fault Zone, seems to have occurred throughout the Neogene. By late Miocene time, an area of localized northwestsoutheast-directed extension within a broad, northwest-trending zone of dextral shear evolved into the ancestral Portland Basin. After Grande Ronde eruptions ceased, at least $440 \mathrm{~m}$ of Columbia Riverderived sediment accumulated within the slowly subsiding basin (Swanson and others, 1993; Mabey and Madin, 1995; Evarts and others, 2009a). Neogene deposition in the Portland Basin culminated in widespread deposition of the Troutdale Formation, which consists of more than $70 \mathrm{~m}$ of Columbia River gravels deposited by progradation and aggradation of a wide braidplain across the Portland Basin (Evarts and others, 2009a).

Since deposition of the Troutdale Formation and later regional incision, the Columbia River and tributary Willamette River have repeatedly aggraded and incised in step with climatically driven sealevel changes. Sea-level rise from the Last Glacial Maximum to the present was about $112 \mathrm{~m}$ (Baker and others, 2010). Resulting incision and subsequent backfilling of the Columbia River valley was about 70 $\mathrm{m}$ in the map area. Such incision and filling, at similar vertical scales, likely occurred many times during the last 2 m.y. during sea-level oscillations. The Quaternary unnamed conglomerate and the Holocene alluvium represent at least two episodes of valley filling. The timing and conditions during Holocene filling are better known. Beginning at about $16 \mathrm{ka}$, aggradation was at first rapid, but it slowed as sea level stabilized (Peterson and others, 2011). The positions of the major channels have remained stable during late Holocene aggradation, and flanking floodplains have aggraded at similar rates by overbank deposition of sand, silt, clay, and organic materials.

Before the last episode of valley filling, cataclysmic floods from ice-dammed Glacial Lake Missoula repeatedly inundated the Portland Basin between 20 and $15 \mathrm{ka}$. Deposits and other evidence for the floods are sparse in the Sauvie Island quadrangle, but the floods deposited thick sheets and immense bars of coarse gravel in the eastern Portland Basin and sand, silt, and clay in backflooded slack-water areas at elevations as high as $400 \mathrm{ft}(120 \mathrm{~m})$.

Throughout the Quaternary, wind entrainment and transport of Columbia River sediment has blanketed upland areas with loess, as much as $37 \mathrm{~m}$ of fine sand, silt, and clay in some locations (Lentz, 1981). Paleosols within the loess show that it accumulated episodically. Most loess was probably 
deposited during glacial periods, although Punke and others (2011) documented Holocene accumulation on upland areas east of the map area.

Holocene dunes, derived from Columbia River deposits, also formed on and adjacent to the modern floodplain. These presently inactive dunes indicate early Holocene episodes of enhanced eolian activity.

\section{Acknowledgments}

Access granted by landowners was essential for mapping in the Sauvie Island quadrangle. We particularly thank Brian Gray, Dave Jensen, and Jim Jackson of the Morse Bros. Angell quarry for allowing us to conduct chemical and paleomagnetic studies in the only large-scale bedrock exposure in the map area. Ian Madin of the Oregon Department of Geology and Mineral Industries contributed chemical analyses of basalt samples from the Angell quarry and vicinity. Jonathan Hagstrum (USGS) provided paleomagnetic data, and Diane Johnson (Washington State University) and Stanley Mertzman (Franklin and Marshall College) performed chemical analyses necessary for interpreting stratigraphy in the Columbia River Basalt Group. Kenneth Bishop, Judith Fierstein, and Michael Clynne provided laboratory facilities. Joseph Mangano assisted with mapping, base-map cartography, and cross sections. Mangano and Karen Wheeler constructed the geodatabase. Drillers' reports for water wells in Oregon were obtained from the Oregon Department of Water Resources Web site (http://apps.wrd.state.or.us/apps/gw/well_log/); reports for wells in Washington were obtained from Washington State Department of Ecology (http://apps.ecy.wa.gov/welllog/). Well locations are taken as described in the drillers' reports and were not field checked. Jonathan Stauberg compiled the well data and constructed preliminary cross sections. We have benefited from discussions with Terry Tolan, Lee Liberty, Ian Madin, Alan Niem, Stephen Reidel, Michael Sawlan, Richard Waitt, and Ray Wells on various aspects of the regional stratigraphy and structure of the Portland Basin. The map and pamphlet were considerably improved by the helpful technical reviews of Ian Madin, Stephen Reidel, and Richard Waitt.

\section{References Cited}

Allison, I.S., 1978, Late Pleistocene sediments and floods in the Willamette Valley: The Ore Bin, v. 40, p. 177-203.

Atwater, B.F., 1986, Pleistocene glacial-lake deposits of the Sanpoil River Valley, northeastern Washington: U.S. Geological Survey Bulletin 1661, 39 p.

Baker, D., Peterson, C., Hemphill-Haley, E., and Twitchell, D., 2010, Latest Pleistocene and Holocene (2-16 ka) sedimentation in the Columbia River estuary, Oregon, USA: Marine Geology, v. 273, p. 8395.

Baksi, A.K., 2013, Timing and duration of volcanism in the Columbia River Basalt Group-A review of existing radiometric data and new constraints on the age of the Steens through Wanapum Basalt extrusion, in Reidel, S.P., Camp, V.E., Ross, M.E., Wolff, J.A., Martin, B.S., Tolan, T.L., and Wells, R.E., eds., The Columbia River flood basalt province: Geological Society of America Special Paper 497, p. 67-85.

Balsillie, J.H., and Benson, G.T., 1971, Evidence for the Portland Hills fault: The Ore Bin, v. 33, p. 109-118.

Barry, T.L., Kelley, S.P., Reidel, S.P., Camp, V.E., Self, S., Jarboe, N.A., Duncan, R.A., and Renne, P.R., 2013, Eruption chronology of the Columbia River Basalt Group, in Reidel, S.P., Camp, V.E., Ross, M.E., Wolff, J.A., Martin, B.S., Tolan, T.L., and Wells, R.E., eds., The Columbia River flood basalt province: Geological Society of America Special Paper 497, p. 45-666. 
Barry, T.L., Self, S., Kelley, S.P., Reidel, S., Hooper, P., and Widdowson, M., 2010, New ${ }^{40} \mathrm{Ar} /{ }^{39} \mathrm{Ar}$ dating of the Grande Ronde lavas, Columbia River Basalts, USA-Implications for duration of flood basalt eruption episodes: Lithos, v. 118, p. 213-222.

Beeson, M.H., Fecht, K.R., Reidel, S.P., and Tolan, T.L., 1985, Regional correlations within the Frenchman Springs Member of the Columbia River Basalt Group-New insights into the middle Miocene tectonics of northwestern Oregon: Oregon Geology, v. 47, p. 87-96.

Beeson, M.H., Perttu, R., and Perttu, J., 1979, The origin of Miocene basalts of coastal Oregon and Washington-An alternative hypothesis: Oregon Geology, v. 41, p. 159-166.

Beeson, M.H., and Tolan, T.L., 1990, The Columbia River Basalt Group in the Cascade Range-A middle Miocene reference datum for structural analysis: Journal of Geophysical Research, v. 96, p. 19547-19559.

Beeson, M.H., Tolan, T.L., and Anderson, J.L., 1989, The Columbia River Basalt Group in western Oregon-Geologic structures and other factors that controlled flow emplacement patterns, in Reidel, S.P., and Hooper, P.R., eds., Volcanism and tectonism in the Columbia River flood-basalt province: Geologic Society of America Special Paper 239, p. 223-246.

Beeson, M.H., Tolan, T.L., and Madin, I.P., 1991, Geologic map of the Portland quadrangle, Multnomah and Washington Counties, Oregon, and Clark County, Washington: Oregon Department of Geology and Mineral Industries Geological Map series GMS-75, scale 1:24,000.

Benito, G., and O’Connor, J.E., 2003, Number and size of last-glacial Missoula floods in the Columbia River valley between the Pasco Basin, Washington and Portland, Oregon: Geological Society of America Bulletin, v. 115, p. 624-638.

Bjornstad, B.N., Fecht, K.R., and Pluhar, C.J., 2001, Long history of pre-Wisconsin ice age cataclysmic floods_Evidence from southeastern Washington State: Journal of Geology, v. 109, p. 695-713.

Blakely, R.J., Beeson, M.H., Cruikshank, K., Wells, R.E., Johnson, A., and Walsh, K., 2004, Gravity study through the Tualatin Mountains, Oregon-Understanding crustal structure and earthquake hazards in the Portland urban area: Bulletin of the Seismological Society of America, v. 94, p. 14021409.

Blakely, R.J., Wells, R.E., Yelin, T.S., Madin, I.P., and Beeson, M.H., 1995, Tectonic setting of the Portland-Vancouver area, Oregon and Washington-Constraints from low-altitude aeromagnetic data: Geological Society of America Bulletin, v. 107, p. 1051-1062.

Blakely, R.J., Wells, R.E., Tolan, T.L., Beeson, M.H., Trehu, A.M., and Liberty, L.M., 2000, New aeromagnetic data reveal large strike-slip(?) faults in the northern Willamette Valley, Oregon: Geological Society of America Bulletin, v. 112, p. 1225-1233.

Bott, J.D.J., and Wong, I.G., 1993, Historical earthquakes in and around Portland, Oregon: Oregon Geology, v. 55, p. 116-122.

Bretz, J.H., 1925, The Spokane flood beyond the Channeled Scablands: Journal of Geology, v. 33, p. 97-115, 236-259.

Bretz, J.H., 1959, Washington's Channeled Scabland: Washington Division of Mines and Geology Bulletin 45, 55 p.

Bretz, J.H., Smith, H.T.U., and Neff, G.E., 1956, Channeled Scabland of Washington-New data and interpretations: Geological Society of America Bulletin, v. 67, p. 957-1049.

Busacca, A.J., 1991, Loess deposits and soils of the Palouse and vicinity, in Morrison, R.G., ed., Quaternary non-glacial geology of the United States; Geological Society of America, Geology of North America, v. K-2, p. 216-218.

Clague, J.J., Barendregt, R., Enkin, R.J., and Foit, F.F., Jr., 2003, Paleomagnetic and tephra evidence for tens of Missoula floods in southern Washington: Geology, v. 31, p. 247-250.

Dehlinger, P., Bowen, R.G., Chiburis, E.F., and Westphal, W.H., 1963, Investigations of the earthquake of November 5, 1962, north of Portland: The Ore Bin, v. 25, no. 4, p. 53-68. 
Evarts, R.C., 2004a, Geologic map of the Saint Helens quadrangle, Columbia County, Oregon and Clark and Cowlitz Counties, Washington: U.S. Geological Survey Scientific Investigations Map 2834, scale 1:24,000, pamphlet 23 p., available at http://pubs.usgs.gov/sim/2004/2834/.

Evarts, R.C., 2004b, Geologic map of the Ridgefield quadrangle, Clark and Cowlitz Counties, Washington: U.S. Geological Survey Scientific Investigations Map 2844, scale 1:24,000, pamphlet 22 p., available at http://pubs.usgs.gov/sim/2004/2844/.

Evarts, R.C., 2004c, Geologic map of the Woodland quadrangle, Columbia County, Oregon, and Cowlitz County, Washington: U.S. Geological Survey Scientific Investigations Map 2827, scale 1:24,000, pamphlet 38 p., available at http://pubs.usgs.gov/sim/2004/2827/.

Evarts, R.C., Conrey, R.M., Fleck, R.J., and Hagstrum, J.T., 2009b, The Boring Volcanic Field of the Portland-Vancouver area, Oregon and Washington-Tectonically anomalous forearc volcanism in an urban setting, in O'Connor, J.E., Dorsey, R.J., and Madin, I.P., eds., Volcanoes to vineyardsGeologic field trips through the dynamic landscape of the Pacific Northwest: Geological Society of America Field Guide 15, p. 253-270, doi:10.1130/2009.fl d015(13).

Evarts, R.C., and O’Connor, J.E., 2008, Geologic map of the Camas quadrangle, Clark County, Washington, and Multnomah County, Oregon, U.S. Geological Survey Scientific Investigations Map 3017, scale 1:24,000, pamphlet 32 p., available at http://pubs.usgs.gov/sim/3017/.

Evarts, R.C., and O’Connor, J.E., 2013, Geologic map of the Washougal quadrangle, Clark County, Washington, and Multnomah County, Oregon, U.S. Geological Survey Scientific Investigations Map 3257, scale 1:24,000, pamphlet 46 p., available at http://pubs.usgs.gov/sim/3257/.

Evarts, R.C., O’Connor, J.E., Wells, R.E., and Madin, I.P., 2009a, The Portland Basin-A (big) river runs through it: GSA Today, v. 19, no. 9, p. 4-10, doi:10.1130/GSATG58A.1.

Evarts, R.C., and Swanson, D.A., 1994, Geologic transect across the Tertiary Cascade Range, southern Washington, in Swanson, D.A., and Haugerud, R.A., eds., Geologic field trips in the Pacific Northwest: Seattle, 1994 Geological Society of America Meeting, University of Washington Department of Geological Sciences, v. 2, p. 2H1-2H31.

Fisher, R., 1953, Dispersion on a sphere: Proceedings of the Royal Society of London, v. A217, p. 295305.

Gates, E.B., 1994, The Holocene sedimentary framework of the lower Columbia River basin: Portland, Oreg., Portland State University, M.S. thesis, 210 p.

Glenn, J.L., 1965, Late Quaternary sedimentation and geologic history of the north Willamette Valley, Oregon: Corvallis, Oregon State University, Ph.D. dissertation, 231 p.

Gradstein, F.M., Ogg, J.G., Schmitz, M.D., and Ogg, G.M., eds., 2012, The geologic time scale 2012: Oxford, Elsevier, 1,144 p.

Gray, J.J., Allen, G.R., and Mack, G.S., 1978, Rock material resources of Clackamas, Columbia, Multnomah, and Washington Counties, Oregon: Oregon Department of Geology and Mineral Industries Special Paper 3, 54 p.

Hodge, E.T., 1938, Geology of the lower Columbia River: Geological Society of America Bulletin, v. 49, p. 831-929.

Hooper, P.R., 2000, Chemical discrimination of Columbia River Basalt flows: Geochemistry, Geophysics, Geosystems, v. 1, no. 2000 GC000040.

Johnson, D.M., Hooper, P.R., and Conrey, R.M., 1999, XRF analysis of rocks and minerals for major and trace elements on a single low dilution Li-tetraborate fused bead: Advances in X-ray Analysis, v. 41, p. 843-867.

Lawes, J.L., III, 1997, Geochemistry, stratigraphy, and provenance of the Portland Hills Silt in the Tualatin Mountains, Portland, Oregon: Portland, Oreg., Portland State University, M.S. thesis, 242 p. Lentz, R.T., 1981, The petrology and stratigraphy of the Portland Hills Silt-A Pacific Northwest loess: Oregon Geology, v. 43, p. 3-10. 
Libbey, F.W., Lowry, W.D., and Mason, R.S., 1945, Ferruginous bauxite deposits in northwestern Oregon: Oregon Department of Geology and Mineral Industries Bulletin 29, 97 p.

Liberty, L.M., Hemphill-Haley, M.A., and Madin, I.P., 2003, The Portland Hills Fault-Uncovering a hidden fault in Portland, Oregon, using high-resolution geophysical methods: Tectonophysics, v. 368, p. 89-103.

Livingston, V.E., 1966, Geology and mineral resources of the Kelso-Cathlamet area, Cowlitz and Wahkiakum Counties, Washington: Washington Division of Mines and Geology Bulletin 54, 110 p.

Long, P.E., and Wood, B.J., 1986, Structures, textures, and cooling histories of Columbia River basalt flows: Geological Society of America Bulletin, v. 97, p. 1144-1155.

Lowry, W.D., and Baldwin, E.M., 1952, Late Cenozoic geology of the lower Columbia River valley, Oregon and Washington: Geological Society of America Bulletin, v. 63, p. 1-24.

Mabey, M.A., and Madin, I.P., 1995, Downhole and seismic cone penetrometer shear-wave velocity measurements for the Portland metropolitan area, 1993 and 1994: Oregon Department of Geology and Mineral Industries Open-File Report O-95-7, 69 p.

Madin, I.P., 1990, Earthquake-hazards geology maps of the Portland metropolitan area, Oregon: Oregon Department of Geology and Mineral Industries Open-File Report O-90-2, scale 1:24,000.

Madin, I.P., and Hempill-Haley, M.A., 2001, The Portland Hills fault at Rowe Middle School: Oregon Geology, v. 63, 47-50.

Madin, I.P., Ma, L., and Niewendorp, C.A., 2008, Preliminary geologic map of the Linnton 7.5' quadrangle, Multnomah, and Washington Counties, Oregon: Oregon Department of Geology and Mineral Industries Open-File Report O-08-06, scale 1:24,000, pamphlet 35 p.

Madin, I.P., and Niewendorp, C.A., 2008, Preliminary geologic map of the Dixie Mountain 7.5' quadrangle, Columbia, Multnomah, and Washington Counties, Oregon: Oregon Department of Geology and Mineral Industries Open-File Report O-08-07, scale 1:24,000, pamphlet 43 p.

Madin, I.P., and Wang, Z., 1999, Relative earthquake hazard maps for selected urban areas in western Oregon-Dallas, Hood River, McMinnville-Dayton-Lafayette, Monmouth-Independence, NewbergDundee, Saint Helens-Columbia City-Scappoose, Sandy, Sheridan-Williamina: Oregon Department of Geology and Mineral Industries Interpretative Map Series IMS-7, scale 1:24,000, pamphlet 119 p.

McCaffrey, R., Qamar, A.I., King, R.W., Wells, R.E., Khazaradze, G., Williams, C.A., Stevens, C., Vollick, J.J., and Zwick, P.C., 2007, Fault locking, block rotation and crustal deformation in the Pacific Northwest: Geophysical Journal International, v. 169, p. 1315-1340.

Mangan, M.T., Wright, T.L., Swanson, D.A., and Byerly, G.R., 1986, Regional correlation of Grande Ronde Basalt flows, Columbia River Basalt Group, Washington, Oregon, and Idaho: Geological Society of America Bulletin, v. 97, p. 1300-1318.

McDonald, E.V., and Busacca, A.J., 1988, Record of pre-late Wisconsin giant floods in the Channeled Scabland interpreted from loess deposits: Geology, v. 16, p. 728-731.

Minervini, J.J., O’Connor, J.E., and Wells, R.E., 2003, Maps showing inundation depths, ice-rafted erratics, and sedimentary facies of late Pleistocene Missoula Floods in the Willamette Valley, Oregon: U.S. Geological Survey Open-File Report 03-408, scale 1:250,000, available at http://pubs.usgs.gov/of/2003/of03-408/.

Mundorff, M.J., 1964, Geology and ground-water conditions of Clark County, Washington, with a description of a major alluvial aquifer along the Columbia River: U.S. Geological Survey WaterSupply Paper 1600, 268 p., scale 1:48,000.

Newton, V.C., Jr., 1969, Subsurface geology of the lower Columbia and Willamette basins: Oregon Department of Geology and Mineral Industries Oil and Gas Investigation, no. 2, 121 p.

O’Connor, J.E., and Baker, V.R., 1992, Magnitudes and implications of peak discharges from glacial Lake Missoula: Geological Society of America Bulletin, v. 104, p. 267-279. 
O’Connor, J.E., and Benito, G., 2009, Late Pleistocene Missoula floods-15,000-20,000 calendar years before present from radiocarbon dating [abs.]: Geological Society of America Abstracts with Programs, v. 41, no. 7, p. 169.

O'Connor, J.E., Sarna-Wojcicki, A.M., Wozniak, K.C., Polette, D.J., and Fleck, R.J., 2001, Origin, extent, and thickness of Quaternary geologic units in the Willamette Valley, Oregon: U.S. Geological Survey Professional Paper 1620, 52 p., 1 plate, available at http://pubs.usgs.gov/pp/1620/.

Peterson, C.D., Minor, R., Peterson, G.L., and Gates, E.B., 2011, Pre- and post-Missoula flood geomorphology of the pre-Holocene ancestral Columbia River valley in the Portland forearc basin, Oregon and Washington, USA: Geomorphology, v. 129, p. 276-293.

Pfaff, V.J., and Beeson, M.H., 1989, Miocene basalt near Astoria, Oregon-Geophysical evidence for Columbia Plateau origin, in Reidel, S.P., and Hooper, P.R, eds., Volcanism and tectonism in the Columbia River flood-basalt province: Geologic Society of America Special Paper 239, p. 143-156. Phillips, W.M., 1987a, comp., Geologic map of the Vancouver quadrangle, Washington: Washington Division of Geology and Earth Resources Open-File Report 87-10, scale 1:100,000, pamphlet 27 p. Phillips, W.M., 1987b, comp., Geologic map of the Mount St. Helens quadrangle, Washington: Washington Division of Geology and Earth Resources Open-File Report 87-4, scale 1:100,000, pamphlet $48 \mathrm{p}$.

Pluhar, C.J., Bjornstad, B.N., Reidel, S.P., Coe, R.S., and Nelson, P.B., 2006, Magnetostratigraphic evidence from the Cold Creek bar for the onset of ice-age cataclysmic floods in eastern Washington during the Early Pleistocene: Quaternary Research, v. 65, p. 123-135.

Pratt, T.L., Odum, J., Stephenson, W., Williams, R., Dadisman, S., Holmes, M., and Haug, B., 2001, Late Pleistocene and Holocene tectonics of the Portland Basin, Oregon and Washington, from highresolution seismic profiling: Bulletin of the Seismological Society of America, v. 91, p. 637-650.

Prescott, J.R., and Hutton, J.T., 1994, Cosmic ray contributions to dose rates for luminescence and ESR dating-Large depths and long-term time variations: Radiation Measurements, v. 23, p. 497-500.

Punke, M.L., Ozbun, T.L., and Resse, J., 2011, Early to late Holocene occupation at the Gee Creek Archaeological sites in the uplands of the Portland basin: Journal of Northwest Anthropology, v. 45, p. 159-197.

Reidel, S.P., 2005, A lava flow without a source-The Cohassett Flow and its compositional components, Sentinel Bluffs Member, Columbia River Basalt Group: Journal of Geology, v. 113, p. $1-21$.

Reidel, S.P., Camp, V.E., Tolan, T.L., and Martin, B.S., 2013, The Columbia River flood basalt province-Stratigraphy, areal extent, volume, and physical volcanology, in Reidel, S.P., Camp, V.E., Ross, M.E., Wolff, J.A., Martin, B.S., Tolan, T.L., and Wells, R.E., eds., The Columbia River flood basalt province: Geological Society of America Special Paper 497, p. 1-43.

Reidel, S.P., and Tolan, T.L, 2013, The Grande Ronde Basalt, Columbia River Basalt Group, in Reidel, S.P., Camp, V.E., Ross, M.E., Wolff, J.A., Martin, B.S., Tolan, T.L., and Wells, R.E., eds., The Columbia River flood basalt province: Geological Society of America Special Paper 497, p. 117-153. Reidel, S.P., Tolan, T.L., Hooper, P.R., Beeson, M.H., Fecht, K.R., Bentley, R.D., and Anderson, J.L., 1989, The Grande Ronde Basalt, Columbia River Basalt Group-Stratigraphic descriptions and correlations in Washington, Oregon, and Idaho, in Reidel, S.P., and Hooper, P.R., eds., Volcanism and tectonism in the Columbia River flood-basalt province: Geological Society of America Special Paper 239, p. 21-53.

Reimer, P.J., and 27 others, 2009, Intcal09 and Marine09 radiocarbon age calibration curves, 0-50,000 years cal BP: Radiocarbon, v. 51, p. 1111-1150.

Ruzek, C.V., and Carpenter, E.J., 1922, Soil survey of Multnomah County, Oregon: U.S. Department of Agriculture, Bureau of Soils, Washington, Government Printing Office, 98 p. 
Ryan, H.F., and Stephenson, A.J., 1995, Cruise report for C1-94-OW-Reconnaissance high resolution Geopulse data acquired for seismic hazard studies along the Columbia River from July 18-22, 1994: U.S. Geological Survey Open-File Report 95-668, 38 p.

Schlicker, H.G., and Deacon, R.J., 1967, Engineering geology of the Tualatin Valley region, Oregon: Oregon Department of Geology and Mineral Industries Bulletin 60, 103 p.

Schmela, R.J., and Palmer, L.A., 1972, Geologic analysis of the Portland Hills-Clackamas River alignment, Oregon: The Ore Bin, v. 34, no. 6, p. 93-103.

Swanson, D.A., Wright, T.L., Hooper, P.R., and Bentley, R.D., 1979, Revisions in stratigraphic nomenclature of the Columbia River Basalt Group: U.S. Geological Survey Bulletin 1457-G, 59 p.

Swanson, R.D., McFarland, W.D., Gonthier, J.B., and Wilkinson, J.M., 1993, A description of hydrogeologic units in the Portland Basin, Oregon and Washington: U.S. Geological Survey WaterResources Investigations Report 90-4196, 56 p., scale 1:100,000.

Tolan, T.L., and Beeson, M.H., 1984, Intracanyon flows of the Columbia River Basalt Group in the lower Columbia River Gorge and their relationship to the Troutdale Formation: Geological Society of America Bulletin, v. 95, p. 463-477.

Tolan, T.L., Martin, B.S., Riedel, S.P., Anderson, J.L., Lindsey, K.A., and Burt, W., 2009, An introduction to stratigraphy, structural geology, and hydrogeology of the Columbia River Flood-Basalt Province-A primer for the GSA Columbia River Basalt Group field trips, in O'Connor, J.E., Dorsey, R.J., and Madin, I.P., eds., Volcanoes to vineyards-Geologic field trips through the dynamic landscape of the Pacific Northwest: Geological Society of America Field Guide 15, p. 599-643, doi:10.1130/2009.fl d015(32).

Tolan, T.L., Reidel, S.P., Beeson, M.H., Anderson, J.L., Fecht, K.R., and Swanson, D.A., 1989, Revisions to the estimates of the areal extent and volume of the Columbia River Basalt Group, in Reidel, S.P., and Hooper, P.R., eds., Volcanism and tectonism in the Columbia River flood-basalt province: Geologic Society of America Special Paper 239, p. 1-20.

Treasher, R.C., 1942, Geologic history of the Portland area: Oregon Department of Geology and Mineral Industries Short Paper no. 7, 17 p.

Trimble, D.E., 1957, Geology of the Portland quadrangle, Oregon-Washington: U.S. Geological Survey Geologic Quadrangle Map GQ-104, scale 1:62,500.

Trimble, D.E., 1963, Geology of Portland, Oregon and adjacent areas: U.S. Geological Survey Bulletin 1119, 119 p., scale 1:62,500.

U.S. Army Corps of Engineers, 1968, Flood profiles, Columbia River and tributaries, Washington and Oregon below Bonneville Dam: Portland, Oregon, U.S. Army Engineer District, accompanies report CL-03-116.

Vogel, M.S., 2005, Quaternary geology of the lower Lewis River valley, Washington-Influence of volcanogenic sedimentation following Mount St. Helens Eruptions: Pullman, Washington State University, M.S. thesis, 65 p.

Waitt, R.B., Jr., 1980, About 40 last-glacial Lake Missoula jökulhlaups through southern Washington: Journal of Geology, v 88, p. 653-679.

Waitt, R.B., Jr., 1985, Case for periodic, colossal jökulhlaups from Pleistocene glacial Lake Missoula: Geological Society of America, v. 96, p. 1271-1286.

Waitt, R.B., Jr., 1994, Scores of gigantic, successively smaller Lake Missoula floods through channeled scabland and Columbia valley, in Swanson, D.A., and Haugerud, R.A., eds., Geologic field trips in the Pacific Northwest: Seattle, University of Washington Department of Geological Sciences, p. 1K1$1 \mathrm{~K} 88$.

Waitt, R.B., Jr., 1996, Numerous colossal Missoula floods through Columbia Gorge and PortlandVancouver basin [abs.]: Geological Society of America Abstracts with Program, v. 28, no. 5, p. 120 121. 
Walsh, K., Peterson, G.L., Beeson, M.H., Wells, R.E., Fleck, R.J., Evarts, R.C., Duvall, A., Blakely, R.J., and Burns, S., 2011, A tunnel runs through it-An inside view of the Tualatin Mountains, Oregon: U.S. Geological Survey Scientific Investigations Map 3144, available at http://pubs.usgs.gov/sim/3144/.

Warne, A.G., and Stanley, D.J., 1995, Sea-level changes as critical factor in development of basin margin sequences-New evidence from late Quaternary record: Journal of Coastal Research Special Issue 17, p. 231-240.

Warren, W.C., and Norbisrath, H., 1946, Stratigraphy of upper Nehalem River basin, northwestern Oregon: American Association of Petroleum Geologists Bulletin, v. 30, p. 213-237.

Wegmann, K.W., and Walsh, T.J., 2001, Landslide hazards mapping in Cowlitz County—A progress report: Washington Geology, v. 29, no. 1/2, p. 30-33.

Wells, R.E., Niem, A.R., Evarts, R.C., and Hagstrum, J.T., 2009, The Columbia River Basalt Group from the gorge to the sea, in O'Connor, J.E., Dorsey, R.J., and Madin, I.P., eds., Volcanoes to vineyards-Geologic field trips through the dynamic landscape of the Pacific Northwest: Geological Society of America Field Guide 15, p. 737-774, doi:10.1130/2009.fl d015(32).

Wells, R.E., Simpson, R.W., Bentley, R.D., Beeson, M.H., Mangan, M.T., and Wright, T.L., 1989, Correlation of Miocene flows of the Columbia River Basalt Group from the central Columbia River Plateau to the coast of Oregon and Washington, in Reidel, S.P., and Hooper, P.R., eds., Volcanism and tectonism in the Columbia River flood-basalt province: Geological Society of America Special Paper 239, p. 113-129.

Wells, R.E., Weaver, C.S., and Blakely, R.J., 1998, Fore-arc migration in Cascadia and its neotectonic significance: Geology, v. 26, p. 759-762.

Whetten, J.T., Kelley, J.C., and Hanson, L.G., 1969, Characteristics of Columbia River sediment and sediment transport: Journal of Sedimentary Petrology, v. 39, p. 1149-1166.

Wilkinson, W.D., Lowry, W.D., and Baldwin, E.M., 1946, Geology of the St.aint Helens quadrangle, Oregon: Oregon Department of Geology and Mineral Industries Bulletin 31, 39 p., scale 1:62,500.

Wolfe, J.A., 1978, A paleobotanical interpretation of Tertiary climates in the Northern Hemisphere: American Scientist, v. 66, p. 694-703.

Wolfe, J.A., and Hopkins, D.M., 1967, Climatic changes recorded by Tertiary land floras in northwestern North America, in Hatai, Kotora, ed., Tertiary correlations and climatic changes in the Pacific: Sendai, Japan, Sendai Printing and Publishing, p. 67-76.

Wong, I.G., Hemphill-Haley, A., Liberty, L.M., and Madin, I.P., 2001, The Portland Hills Fault-An earthquake generator or just another old fault?: Oregon Geology, v. 63, p. 39-50.

Yeats, R.S., Graven, E.P., Werner, K.S., Goldfinger, Chris, and Popowski, T.A., 1996, Tectonics of the Willamette Valley, Oregon, in Rogers, A.M., Walsh, T.J., Kockelman, W.J., and Priest, G.R., eds., Assessing earthquake hazards and reducing risk in the Pacific Northwest-Vol. I: U.S. Geological Survey Professional Paper 1560, p. 183-222.

Yelin, T.S., and Patton, H.J., 1991, Seismotectonics of the Portland, Oregon, region: Seismological Society of America Bulletin, v. 81, p. 109-130.

Zuffa, G.G., Normark, W.R., Serra, F., and Brunner, C.A., 2000, Turbidite megabeds in an oceanic rift valley recording jökulhlaups of late Pleistocene glacial lakes of the western United States: Journal of Geology, v. 108, p. 253-274. 
Table 1. Chemical analyses of the Grande Ronde Basalt, Sauvie Island quadrangle.

[Chemical analyses by X-ray fluorescence: $\mathrm{FeO}^{*}$, total Fe calculated as $\mathrm{FeO}$; LOI, loss on ignition; $\mathrm{Mg} \#$, atomic ratio $100 \mathrm{Mg} /\left(\mathrm{Mg}+\mathrm{Fe}{ }^{2+}\right)$, with $\mathrm{Fe}^{2+}$ set to $0.85 \times \mathrm{Fe}^{\text {total }}$; -- , not determined; ppm, parts per million. Analyses by D.M. Johnson Cornelius at Peter Hooper

GeoAnalytical Laboratory of Washington State University, Pullman, Wash., using methods described in Johnson and others (1999), except for samples labeled PDX, which were collected by Ian Madin and analyzed by S.R. Mertzman at Franklin and Marshall College, Lancaster, Penn., using methods described in appendix B of Madin and others (2008). Polarity is laboratory-determined paleomagnetic polarity: N, normal; R, reversed (see table 2 for details); --, not determined. Latitudes and longitudes in North American Datum of 1983 coordinates]

\begin{tabular}{|c|c|c|c|c|c|c|c|c|c|}
\hline Map No. & 1 & 2 & 3 & 4 & 5 & 6 & 7 & 8 & 9 \\
\hline Field sample No. & 06HB-N15Ar & 06HB-N15B & T6135 1 & 04HB-N08 & 04HB-N05 & $\mathrm{T}_{6127^{1}}$ & $\mathrm{~T}_{6143}{ }^{1}$ & 04HB-N07B ${ }^{1}$ & 04HB-N06B ${ }^{1}$ \\
\hline Latitude (N.) & $45^{\circ} 37.716^{\prime}$ & $45^{\circ} 37.709^{\prime}$ & $45^{\circ} 37.618^{\prime}$ & $45^{\circ} 41.390^{\prime}$ & $45^{\circ} 41.896^{\prime}$ & $45^{\circ} 37.583^{\prime}$ & $45^{\circ} 37.248^{\prime}$ & $45^{\circ} 41.713^{\prime}$ & $45^{\circ} 41.793$ \\
\hline Longitude (W.) & $122^{\circ} 49.515^{\prime}$ & $122^{\circ} 49.528^{\prime}$ & $122^{\circ} 49.685^{\prime}$ & $122^{\circ} 52.341^{\prime}$ & $122^{\circ} 52.324^{\prime}$ & $122^{\circ} 49.771^{\prime}$ & $122^{\circ} 20.261^{\prime}$ & $122^{\circ} 52.218^{\prime}$ & $122^{\circ} 52.309^{\prime}$ \\
\hline Map unit & Tggc & Tggc & Tggc & Tgo & Tgo & Tgo & Tgo & Tgo & Tgo \\
\hline Polarity & -- & -- & $\mathrm{R}$ & $\mathrm{N}$ & $\mathrm{N}$ & $\mathrm{N}$ & $\mathrm{N}$ & $\mathrm{N}$ & -- \\
\hline \multicolumn{10}{|c|}{ Analyses as reported (weight percent) } \\
\hline $\mathrm{SiO}_{2}$ & 54.56 & 55.22 & 55.43 & 55.66 & 55.78 & 55.74 & 56.04 & 56.35 & 55.67 \\
\hline $\mathrm{TiO}_{2}$ & 2.08 & 2.00 & 2.00 & 1.96 & 1.94 & 1.85 & 1.97 & 1.81 & 2.05 \\
\hline $\mathrm{Al}_{2} \mathrm{O}_{3}$ & 13.25 & 14.01 & 13.74 & 13.66 & 13.62 & 14.21 & 13.89 & 13.82 & 13.85 \\
\hline $\mathrm{Fe}_{2} \mathrm{O}_{3}$ & -- & -- & -- & -- & -- & -- & -- & -- & -- \\
\hline & 11.91 & 11.17 & 9.90 & 11.19 & 10.94 & 9.09 & 9.46 & 10.73 & 10.59 \\
\hline $\mathrm{MnO}$ & 0.19 & 0.19 & 0.20 & 0.19 & 0.18 & 0.17 & 0.19 & 0.18 & 0.18 \\
\hline $\mathrm{MgO}$ & 3.27 & 3.66 & 3.46 & 3.43 & 3.55 & 3.98 & 3.46 & 3.52 & 3.53 \\
\hline $\mathrm{CaO}$ & 6.74 & 7.12 & 6.97 & 6.91 & 6.89 & 7.53 & 7.05 & 7.05 & 7.02 \\
\hline $\mathrm{Na}_{2} \mathrm{O}$ & 3.02 & 3.13 & 3.02 & 3.22 & 3.35 & 3.00 & 3.08 & 3.18 & 3.21 \\
\hline $\mathrm{K}_{2} \mathrm{O}$ & 2.01 & 1.71 & 1.97 & 1.90 & 1.64 & 1.85 & 2.00 & 1.84 & 1.84 \\
\hline $\mathrm{P}_{2} \mathrm{O}_{5}$ & 0.35 & 0.33 & 0.35 & 0.34 & 0.34 & 0.30 & 0.33 & 0.30 & 0.34 \\
\hline LOI & -- & -- & -- & -- & -- & -- & -- & -- & -- \\
\hline Total & 97.39 & 98.55 & 97.03 & 98.45 & 98.23 & 97.73 & 97.48 & 98.79 & 98.29 \\
\hline \multicolumn{10}{|c|}{ Analyses recalculated volatile-free and normalized to 100 percent, with all Fe as FeO (weight percent) } \\
\hline $\mathrm{SiO}_{2}$ & 56.02 & 56.03 & 57.13 & 56.53 & 56.78 & 57.03 & 57.49 & 57.04 & 56.63 \\
\hline $\mathrm{TiO}_{2}$ & 2.14 & 2.03 & 2.06 & 1.99 & 1.98 & 1.89 & 2.02 & 1.83 & 2.09 \\
\hline $\mathrm{Al}_{2} \mathrm{O}_{3}$ & 13.61 & 14.21 & 14.16 & 13.88 & 13.86 & 14.54 & 14.25 & 13.99 & 14.09 \\
\hline $\mathrm{FeO}^{*}$ & 12.23 & 11.33 & 10.21 & 11.37 & 11.14 & 9.30 & 9.71 & 10.86 & 10.77 \\
\hline $\mathrm{MnO}$ & 0.20 & 0.19 & 0.20 & 0.19 & 0.18 & 0.18 & 0.19 & 0.19 & 0.19 \\
\hline $\mathrm{MgO}$ & 3.35 & 3.72 & 3.56 & 3.48 & 3.62 & 4.07 & 3.55 & 3.56 & 3.60 \\
\hline $\mathrm{CaO}$ & 6.92 & 7.23 & 7.18 & 7.02 & 7.02 & 7.70 & 7.23 & 7.14 & 7.15 \\
\hline $\mathrm{Na}_{2} \mathrm{O}$ & 3.10 & 3.18 & 3.11 & 3.27 & 3.41 & 3.07 & 3.16 & 3.22 & 3.26 \\
\hline $\mathrm{K}_{2} \mathrm{O}$ & 2.06 & 1.73 & 2.03 & 1.93 & 1.67 & 1.89 & 2.05 & 1.86 & 1.87 \\
\hline $\mathrm{P}_{2} \mathrm{O}_{5}$ & 0.36 & 0.34 & 0.36 & 0.34 & 0.34 & 0.31 & 0.34 & 0.31 & 0.35 \\
\hline Mg\# & 36.5 & 40.8 & 42.3 & 39.1 & 40.5 & 47.9 & 43.4 & 40.8 & 41.2 \\
\hline \multicolumn{10}{|c|}{ Trace element analyses (ppm) } \\
\hline $\mathrm{Ba}$ & 719 & 709 & 691 & 701 & 676 & 654 & 727 & 705 & 735 \\
\hline $\mathrm{Rb}$ & 52 & 49 & 52 & 51 & 44 & 47 & 53 & 52 & 53 \\
\hline $\mathrm{Sr}$ & 307 & 334 & 324 & 305 & 308 & 329 & 336 & 306 & 319 \\
\hline $\mathrm{Y}$ & 36 & 35 & 37 & 36 & 35 & 35 & 36 & 35 & 40 \\
\hline $\mathrm{Zr}$ & 186 & 176 & 186 & 183 & 180 & 172 & 194 & 182 & 185 \\
\hline $\mathrm{Nb}$ & 11.9 & 10.9 & 12.3 & 12.8 & 12.3 & 11.3 & 12.2 & 13.3 & 13.1 \\
\hline $\mathrm{Ni}$ & 10 & 12 & 10 & 10 & 10 & 13 & 7 & 9 & 13 \\
\hline $\mathrm{Cu}$ & 20 & 22 & 15 & 14 & 15 & 18 & 12 & 11 & 20 \\
\hline $\mathrm{Zn}$ & 124 & 124 & 125 & 122 & 122 & 120 & 123 & 120 & 128 \\
\hline $\mathrm{Cr}$ & 5 & 12 & 11 & 12 & 8 & 16 & 7 & 8 & 15 \\
\hline Sc & 32 & 32 & 31 & 30 & 33 & 35 & 31 & 32 & 34 \\
\hline $\mathrm{V}$ & 349 & 338 & 328 & 325 & 331 & 318 & 310 & 301 & 346 \\
\hline
\end{tabular}

${ }^{1}$ Original composition likely modified by weathering as deduced from low analytical totals ( $<98$ weight percent anhydrous), high LOI ( $>2.00$ weight percent), or low $\mathrm{FeO}^{*}(<11$ weight percent) contents. 
Table 1. Chemical analyses of the Grande Ronde Basalt, Sauvie Island quadrangle.-Continued

\begin{tabular}{|c|c|c|c|c|c|c|c|c|c|}
\hline Map No. & 10 & 11 & 12 & 13 & 14 & 15 & 16 & 17 & 18 \\
\hline Field sample No. & 04HB-N04 ${ }^{1,2}$ & $04 \mathrm{HB}-\mathrm{N} 02^{1}$ & $04 \mathrm{HB}-\mathrm{N} 03^{1}$ & PDX-1421 ${ }^{1}$ & PDX-1419 1 & 04HB-N09 & $04 \mathrm{HB}-\mathrm{N} 11^{3}$ & 04HB-N12A & 04HB-N13 \\
\hline Latitude (N.) & $45^{\circ} 41.838^{\prime}$ & $45^{\circ} 42.224^{\prime}$ & $45^{\circ} 41.949^{\prime}$ & $45^{\circ} 37.999^{\prime}$ & $45^{\circ} 37.988^{\prime}$ & $45^{\circ} 38.470^{\prime}$ & $45^{\circ} 37.461^{\prime}$ & $45^{\circ} 38.581^{\prime}$ & $45^{\circ} 38.152^{\prime}$ \\
\hline Longitude (W.) & $122^{\circ} 52.692^{\prime}$ & $122^{\circ} 52.407^{\prime}$ & $122^{\circ} 52.461^{\prime}$ & $122^{\circ} 49.963^{\prime}$ & $122^{\circ} 50.050^{\prime}$ & $122^{\circ} 50.139^{\prime}$ & $122^{\circ} 48.936^{\prime}$ & $122^{\circ} 51.377^{\prime}$ & $122^{\circ} 51.593^{\prime}$ \\
\hline Map unit & Tgo & Tgo & Tgo & Tgo & Tgo & Tgww & Tgww & Tgww & Tgww \\
\hline Polarity & -- & -- & -- & -- & -- & $\mathrm{N}$ & -- & -- & -- \\
\hline \multicolumn{10}{|c|}{ Analyses as reported (weight percent) } \\
\hline $\mathrm{SiO}_{2}$ & 55.01 & 55.18 & 56.82 & 54.74 & 53.63 & 53.88 & 54.39 & 54.94 & 54.92 \\
\hline $\mathrm{TiO}_{2}$ & 1.93 & 1.92 & 1.83 & 1.94 & 1.95 & 2.02 & 2.01 & 2.03 & 2.02 \\
\hline $\mathrm{Al}_{2} \mathrm{O}_{3}$ & 13.48 & 13.54 & 13.92 & 13.82 & 14.41 & 13.41 & 13.48 & 13.68 & 13.49 \\
\hline $\mathrm{Fe}_{2} \mathrm{O}_{3}$ & -- & -- & -- & 3.37 & 6.48 & -- & -- & -- & -- \\
\hline $\mathrm{FeO}^{*}$ & 11.19 & 10.46 & 9.72 & 7.50 & 5.26 & 12.11 & 12.45 & 11.34 & 12.54 \\
\hline $\mathrm{MnO}$ & 0.19 & 0.19 & 0.16 & 0.17 & 0.15 & 0.21 & 0.19 & 0.20 & 0.22 \\
\hline $\mathrm{MgO}$ & 3.42 & 3.45 & 3.40 & 3.52 & 3.18 & 3.84 & 3.88 & 3.83 & 3.83 \\
\hline $\mathrm{CaO}$ & 6.87 & 6.95 & 7.06 & 7.03 & 6.59 & 7.55 & 7.47 & 7.46 & 7.54 \\
\hline $\mathrm{Na}_{2} \mathrm{O}$ & 3.22 & 3.10 & 3.04 & 2.91 & 2.92 & 3.04 & 3.26 & 3.30 & 3.27 \\
\hline $\mathrm{K}_{2} \mathrm{O}$ & 1.76 & 1.98 & 1.93 & 1.93 & 1.37 & 1.68 & 1.37 & 1.37 & 1.36 \\
\hline $\mathrm{P}_{2} \mathrm{O}_{5}$ & 0.33 & 0.33 & 0.42 & 0.32 & 0.33 & 0.31 & 0.31 & 0.31 & 0.31 \\
\hline LOI & -- & -- & -- & 2.59 & 4.12 & -- & -- & -- & -- \\
\hline Total & 97.39 & 97.10 & 98.30 & 99.84 & 100.39 & 98.04 & 98.80 & 98.44 & 99.50 \\
\hline \multicolumn{10}{|c|}{ Analyses recalculated volatile-free and normalized to 100 percent, with all Fe as FeO (weight percent) } \\
\hline $\mathrm{SiO}_{2}$ & 56.49 & 56.83 & 57.81 & 57.49 & 56.48 & 54.96 & 55.05 & 55.80 & 55.20 \\
\hline $\mathrm{TiO}_{2}$ & 1.99 & 1.98 & 1.87 & 2.02 & 2.00 & 2.06 & 2.04 & 2.06 & 2.03 \\
\hline $\mathrm{Al}_{2} \mathrm{O}_{3}$ & 13.84 & 13.95 & 14.16 & 14.25 & 14.26 & 13.67 & 13.65 & 13.90 & 13.55 \\
\hline $\mathrm{FeO}^{*}$ & 11.49 & 10.77 & 9.89 & 9.71 & 10.87 & 12.35 & 12.60 & 11.52 & 12.60 \\
\hline $\mathrm{MnO}$ & 0.19 & 0.20 & 0.17 & 0.19 & 0.18 & 0.21 & 0.20 & 0.20 & 0.22 \\
\hline $\mathrm{MgO}$ & 3.51 & 3.55 & 3.46 & 3.55 & 3.63 & 3.92 & 3.93 & 3.89 & 3.85 \\
\hline $\mathrm{CaO}$ & 7.05 & 7.16 & 7.18 & 7.23 & 7.25 & 7.70 & 7.56 & 7.57 & 7.58 \\
\hline $\mathrm{Na}_{2} \mathrm{O}$ & 3.31 & 3.19 & 3.09 & 3.16 & 3.00 & 3.10 & 3.30 & 3.35 & 3.29 \\
\hline $\mathrm{K}_{2} \mathrm{O}$ & 1.80 & 2.04 & 1.96 & 2.05 & 1.99 & 1.71 & 1.38 & 1.39 & 1.36 \\
\hline $\mathrm{P}_{2} \mathrm{O}_{5}$ & 0.34 & 0.34 & 0.43 & 0.34 & 0.33 & 0.31 & 0.31 & 0.32 & 0.31 \\
\hline Mg\# & 39.0 & 40.9 & 42.3 & 41.2 & 37.5 & 39.9 & 39.5 & 41.5 & 39.0 \\
\hline \multicolumn{10}{|c|}{ Trace element analyses (ppm) } \\
\hline $\mathrm{Ba}$ & 691 & 690 & 829 & 752 & 307 & 553 & 548 & 563 & 552 \\
\hline $\mathrm{Rb}$ & 48 & 51 & 56 & 55 & 39 & 40 & 37 & 34 & 37 \\
\hline $\mathrm{Sr}$ & 302 & 319 & 322 & 343 & 342 & 304 & 302 & 310 & 302 \\
\hline $\mathrm{Y}$ & 35 & 36 & 39 & 42 & 44 & 36 & 37 & 38 & 37 \\
\hline $\mathrm{Zr}$ & 180 & 189 & 184 & 211 & 209 & 171 & 171 & 175 & 173 \\
\hline $\mathrm{Nb}$ & 12.2 & 12.8 & 12.5 & 13.4 & 13.6 & 12.4 & 11.9 & 12.6 & 11.9 \\
\hline $\mathrm{Ni}$ & 12 & 9 & 8 & 4 & 5 & 8 & 8 & 9 & 9 \\
\hline $\mathrm{Cu}$ & 15 & 13 & 12 & 10 & 9 & 7 & 10 & 10 & 11 \\
\hline $\mathrm{Zn}$ & 123 & 120 & 121 & 137 & 135 & 124 & 127 & 130 & 124 \\
\hline $\mathrm{Cr}$ & 13 & 7 & 7 & 18 & 19 & 10 & 11 & 11 & 13 \\
\hline Sc & 31 & 33 & 33 & 29 & 32 & 35 & 34 & 36 & 35 \\
\hline V & 324 & 307 & 300 & 305 & 291 & 376 & 371 & 375 & 368 \\
\hline
\end{tabular}

${ }^{2}$ Site located in adjacent Dixie Mountain quadrangle.

${ }^{3}$ Site located in adjacent Linnton quadrangle. 
Table 1. Chemical analyses of the Grande Ronde Basalt, Sauvie Island quadrangle.-Continued

\begin{tabular}{|c|c|c|c|c|c|c|c|c|}
\hline Map No. & 19 & 20 & 21 & 22 & 23 & 24 & 25 & 26 \\
\hline Field sample No. & $\mathrm{T}_{6153}{ }^{1}$ & 04HB-J20 ${ }^{1}$ & $04 \mathrm{HB}-\mathrm{N} 10^{1}$ & $04 \mathrm{HB}-\mathrm{J}_{2} 3^{1}$ & PDX-1418 ${ }^{1}$ & PDX-1422 1,3 & PDX-1423 ${ }^{1}$ & PDX-1427B ${ }^{1}$ \\
\hline Latitude (N.) & $45^{\circ} 37.713^{\prime}$ & $45^{\circ} 38.191^{\prime}$ & $45^{\circ} 38.246^{\prime}$ & $45^{\circ} 38.153^{\prime}$ & $45^{\circ} 38.059^{\prime}$ & $45^{\circ} 37.447^{\prime}$ & $45^{\circ} 37.592^{\prime}$ & $45^{\circ} 37.708^{\prime}$ \\
\hline Longitude (W.) & $122^{\circ} 49.771^{\prime}$ & $122^{\circ} 51.774^{\prime}$ & $122^{\circ} 49.812^{\prime}$ & $122^{\circ} 51.790^{\prime}$ & $122^{\circ} 49.883^{\prime}$ & $122^{\circ} 50.304^{\prime}$ & $122^{\circ} 49.997^{\prime}$ & $122^{\circ} 49.247^{\prime}$ \\
\hline Map unit & Tgww & Tgww & Tgww & Tgww & Tgww & Tgww & Tgww & Tgww \\
\hline Polarity & $\mathrm{N}$ & $\mathrm{N}$ & $\mathrm{N}$ & -- & -- & -- & -- & -- \\
\hline \multicolumn{9}{|c|}{ Analyses as reported (weight percent) } \\
\hline $\mathrm{SiO}_{2}$ & 57.00 & 56.57 & 56.58 & 55.33 & 57.07 & 54.02 & 53.57 & 55.45 \\
\hline $\mathrm{TiO}_{2}$ & 2.21 & 2.16 & 2.17 & 2.08 & 2.20 & 2.11 & 2.07 & 2.14 \\
\hline $\mathrm{Al}_{2} \mathrm{O}_{3}$ & 14.18 & 13.92 & 13.98 & 14.01 & 14.39 & 14.28 & 13.72 & 13.94 \\
\hline $\mathrm{Fe}_{2} \mathrm{O}_{3}$ & -- & -- & -- & -- & 2.29 & 4.64 & 6.37 & 3.04 \\
\hline $\mathrm{FeO}^{*}$ & 7.69 & 9.80 & 9.33 & 10.11 & 6.26 & 5.98 & 6.18 & 7.61 \\
\hline $\mathrm{MnO}$ & 0.18 & 0.19 & 0.17 & 0.19 & 0.19 & 0.16 & 0.19 & 0.20 \\
\hline $\mathrm{MgO}$ & 3.08 & 3.22 & 3.30 & 3.74 & 3.27 & 3.44 & 3.45 & 3.36 \\
\hline $\mathrm{CaO}$ & 6.75 & 6.87 & 6.91 & 7.60 & 6.97 & 7.18 & 7.22 & 7.01 \\
\hline $\mathrm{Na}_{2} \mathrm{O}$ & 3.23 & 3.16 & 3.31 & 3.34 & 3.28 & 2.95 & 3.04 & 3.08 \\
\hline $\mathrm{K}_{2} \mathrm{O}$ & 2.09 & 1.96 & 1.98 & 1.58 & 2.00 & 1.46 & 1.35 & 2.03 \\
\hline $\mathrm{P}_{2} \mathrm{O}_{5}$ & 0.40 & 0.37 & 0.37 & 0.32 & 0.39 & 0.33 & 0.32 & 0.39 \\
\hline LOI & -- & -- & -- & -- & 1.91 & 3.68 & 2.82 & 1.73 \\
\hline Total & 96.81 & 98.24 & 98.10 & 98.32 & 100.22 & 100.23 & 100.30 & 99.98 \\
\hline \multicolumn{9}{|c|}{ Analyses recalculated as volatile-free and normalized to 100 percent, with all Fe as FeO (weight percent) } \\
\hline $\mathrm{SiO}_{2}$ & 58.88 & 57.59 & 57.68 & 56.28 & 58.19 & 56.22 & 55.32 & 56.61 \\
\hline $\mathrm{TiO}_{2}$ & 2.29 & 2.19 & 2.21 & 2.12 & 2.24 & 2.20 & 2.14 & 2.18 \\
\hline $\mathrm{Al}_{2} \mathrm{O}_{3}$ & 14.64 & 14.17 & 14.25 & 14.25 & 14.67 & 14.86 & 14.17 & 14.23 \\
\hline $\mathrm{FeO}^{*}$ & 7.94 & 9.98 & 9.51 & 10.28 & 8.49 & 10.57 & 12.30 & 10.56 \\
\hline $\mathrm{MnO}$ & 0.18 & 0.19 & 0.18 & 0.20 & 0.19 & 0.17 & 0.20 & 0.20 \\
\hline $\mathrm{MgO}$ & 3.18 & 3.27 & 3.36 & 3.81 & 3.33 & 3.58 & 3.56 & 3.43 \\
\hline $\mathrm{CaO}$ & 6.98 & 7.00 & 7.04 & 7.73 & 7.11 & 7.47 & 7.46 & 7.2 \\
\hline $\mathrm{Na}_{2} \mathrm{O}$ & 3.34 & 3.22 & 3.37 & 3.40 & 3.34 & 3.07 & 3.14 & 3.14 \\
\hline $\mathrm{K}_{2} \mathrm{O}$ & 2.16 & 2.00 & 2.02 & 1.60 & 2.04 & 1.52 & 1.39 & 2.07 \\
\hline $\mathrm{P}_{2} \mathrm{O}_{5}$ & 0.41 & 0.38 & 0.38 & 0.33 & 0.40 & 0.34 & 0.33 & 0.40 \\
\hline $\mathrm{Mg} \#$ & 41.7 & 40.8 & 42.6 & 43.7 & 45.2 & 41.5 & 37.8 & 40.5 \\
\hline \multicolumn{9}{|c|}{ Trace element analyses (ppm) } \\
\hline $\mathrm{Ba}$ & 768 & 762 & 722 & 644 & 897 & 817 & 857 & 763 \\
\hline $\mathrm{Rb}$ & 59 & 52 & 54 & 42 & 58 & 41 & 41 & 57 \\
\hline $\mathrm{Sr}$ & 364 & 341 & 340 & 331 & 363 & 350 & 332 & 337 \\
\hline $\mathrm{Y}$ & 42 & 41 & 40 & 40 & 48 & 47 & 40 & 45 \\
\hline $\mathrm{Zr}$ & 203 & 195 & 194 & 179 & 225 & 208 & 193 & 217 \\
\hline $\mathrm{Nb}$ & 13.4 & 12.4 & 12.8 & 12.0 & 13.4 & 12.8 & 11.9 & 13.4 \\
\hline $\mathrm{Ni}$ & 5 & 4 & 8 & 8 & 3 & 4 & 5 & 2 \\
\hline $\mathrm{Cu}$ & 9 & 8 & 9 & 11 & 4 & 9 & 6 & 4 \\
\hline $\mathrm{Zn}$ & 141 & 139 & 136 & 146 & 163 & 160 & 139 & 151 \\
\hline $\mathrm{Cr}$ & 6 & 6 & 11 & 10 & 23 & 21 & 27 & 20 \\
\hline Sc & 34 & 33 & 35 & 36 & 29 & 33 & 31 & 29 \\
\hline $\mathrm{V}$ & 350 & 336 & 365 & 386 & 357 & 373 & 372 & 351 \\
\hline
\end{tabular}


Table 2. Paleomagnetic data for Columbia River Basalt flows, Sauvie Island quadrangle.

[ $\lambda_{\text {SITE }}$ and $\phi_{\text {SITE }}$, latitude and west longitude of site (degrees); Strike/Dip, strike and dip of host rock (strike $90^{\circ}$ counterclockwise of dip direction); $I_{c}, D_{c}$, paleomagnetic directions corrected for structural tilt; $N / N_{O}$, number of samples analyzed/number of samples collected; $R$, vector sum of $N$ unit vectors; $k$, concentration parameter (Fisher, 1953), for means calculated using Bingham statistics, $R$ is not calculated; $\alpha_{95}$, radius of $95 \%$ confidence (degrees); $\lambda_{P}$ and $\phi_{P}$, latitude and east longitude of virtual geomagnetic pole (degrees) corrected for structural tilt. Analyses by J.T. Hagstrum, U.S. Geological Survey, Menlo Park, Calif. Latitudes and longitudes in North American Datum of 1983 coordinates]

\begin{tabular}{|c|c|c|c|c|c|c|c|c|c|c|c|c|c|}
\hline $\begin{array}{c}\text { Field } \\
\text { sample no. }\end{array}$ & $\begin{array}{l}\text { Laboratory } \\
\text { sample no. }\end{array}$ & $\begin{array}{l}\text { Map } \\
\text { unit }\end{array}$ & $\lambda_{\text {SITE }}$ & $\phi$ SITE & Strike/Dip & $I_{c}$ & $D_{c}$ & $N / N_{0}$ & $R$ & $k$ & $\alpha 95$ & $\lambda_{p}$ & $\phi p$ \\
\hline 04HB-N09 & T6057E & Tgww & 45.64117 & -122.83565 & $325 / 15$ & 33.6 & 351.3 & $8 / 8$ & 7.9507 & 142 & 4.7 & 61.8 & 74.8 \\
\hline 04HB-N10 & T6065E & Tgww & 45.63743 & -122.83020 & $322 / 18$ & 15.3 & 341.6 & $7 / 8$ & 6.9864 & 442 & 2.9 & 48.1 & 85.1 \\
\hline 04HB-J20 & T6081E & Tgww & 45.63652 & -122.86290 & $0 / 0$ & 27.6 & 353.0 & $8 / 8$ & 7.9539 & 152 & 4.5 & 58.5 & 70.2 \\
\hline T6153E & T6153E & Tgww & 45.62855 & -122.82952 & $331 / 11$ & 26.1 & 330.6 & $8 / 8$ & 7.8632 & 51 & 7.8 & 49.6 & 104.6 \\
\hline 04HB-N05 & T6041E & Tgo & 45.69827 & -122.87207 & $355 / 15$ & 56.2 & 0.0 & $7 / 8$ & 6.9572 & 140 & 5.1 & 81.1 & 57.1 \\
\hline 04HB-N07B & T6049E & Tgo & 45.69522 & -122.87030 & $355 / 15$ & 50.5 & 350.0 & $7 / 8$ & 6.9162 & 72 & 7.2 & 73.6 & 88.8 \\
\hline 04HB-N08 & T6073E & Tgo & 45.68983 & -122.87235 & $355 / 15$ & 53.1 & 18.8 & $7 / 8$ & 6.9273 & 83 & 6.7 & 71.3 & 0.5 \\
\hline T6143E & T6143E & Tgo & 45.62803 & -122.82517 & $331 / 13$ & 55.7 & 17.4 & $9 / 10$ & 8.9264 & 109 & 5.1 & 73.9 & 356.7 \\
\hline T6127E & T6127E & Tgo & 45.62638 & -122.82952 & $331 / 6$ & 60.9 & 8.9 & $8 / 8$ & 7.9647 & 199 & 4.1 & 82.6 & 353.9 \\
\hline T6135E & T6135E & Tggc & 45.62697 & -122.82808 & $331 / 9$ & -46.7 & 200.1 & $5 / 8$ & 4.9857 & 279 & 4.6 & 66.2 & 8.3 \\
\hline
\end{tabular}




\section{Table 3. Summary of luminescence age determinations in vicinity of Sauvie Island quadrangle.}

[No luminescence age determinations were made from samples within Sauvie Island quadrangle; samples tabulated here are from correlative units in adjacent quadrangles. Ages from blue-light optically stimulated luminescence (OSL) on quartz using single aliquot regeneration and from infrared stimulated luminescence (IRSL) on polymineralic silt using multiple

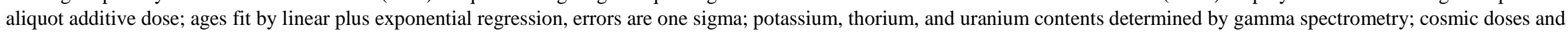
attenuation with depth were calculated using methods of Prescott and Hutton (1994); n values indicate number of replicated equivalent dose estimates used to calculate mean for OSL determinations; --, no replicates for IRSL determinations. Figures in parentheses indicate total number of measurements made, including failed runs that have unusable data. Ages

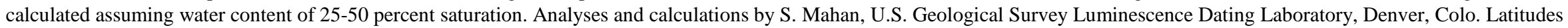
and longitudes in North American Datum of 1983 coordinates]

\begin{tabular}{|c|c|c|c|c|c|c|c|c|c|c|c|c|c|}
\hline \multirow{2}{*}{ Field sample No. } & \multirow{2}{*}{ Quadrangle } & \multicolumn{2}{|c|}{ Location } & \multirow{2}{*}{$\begin{array}{l}\text { Stratigraphic } \\
\text { context }\end{array}$} & \multirow{2}{*}{$\begin{array}{l}\text { Sample water } \\
\text { content, in } \\
\text { weight } \\
\text { percent (value } \\
\text { at saturation) }\end{array}$} & \multirow{2}{*}{$\begin{array}{c}\text { Potassium, } \\
\text { in weight } \\
\text { percent }\end{array}$} & \multirow{2}{*}{$\begin{array}{l}\text { Thorium, } \\
\text { in parts per } \\
\text { million }\end{array}$} & \multirow{2}{*}{$\begin{array}{l}\text { Uranium, } \\
\text { in parts per } \\
\text { million }\end{array}$} & \multirow{2}{*}{$\begin{array}{c}\text { Cosmic dose } \\
\text { additions, in } \\
\text { Grays per } \\
\text { thousand } \\
\text { years }\end{array}$} & \multirow{2}{*}{$\begin{array}{l}\text { Total dose } \\
\text { rate, in Grays } \\
\text { per thousand } \\
\text { years }^{1}\end{array}$} & \multirow{2}{*}{$\begin{array}{l}\text { Equivalent } \\
\text { dose, in } \\
\text { Grays }\end{array}$} & \multirow{2}{*}{$n^{2}$} & \multirow{2}{*}{$\begin{array}{c}\text { Age, in } \\
\text { thousands of } \\
\text { years }\end{array}$} \\
\hline & & $\begin{array}{l}\text { Latitude } \\
\quad \mathrm{N} .\end{array}$ & $\begin{array}{l}\text { Longitude } \\
\text { W. }\end{array}$ & & & & & & & & & & \\
\hline RW07-08/22-09:30 & Saint Helens & $45^{\circ} 46.113^{\prime}$ & $122^{\circ} 52.168^{\prime}$ & $\begin{array}{l}\text { QTc, } 4.1 \text { m below } \\
\text { surface within } \\
\text { 30-cm-thick } \\
\text { sand lens }\end{array}$ & $35(35)$ & $1.74 \pm 0.07$ & $8.10 \pm 0.37$ & $1.90 \pm 0.16$ & $0.28 \pm 0.01$ & $3.14 \pm 0.1^{1}$ & $53.8 \pm 0.54^{1}$ & -- & $17.1 \pm 1.13^{1,2}$ \\
\hline RW07-08/22-11:50 & Saint Helens & $45^{\circ} 47.037^{\prime}$ & $122^{\circ} 51.083^{\prime}$ & $\begin{array}{l}\text { QTc, } 6.8 \mathrm{~m} \text { below } \\
\text { surface within } \\
\text { thin }(<20 \mathrm{~cm} \\
\text { thick) sand lens }\end{array}$ & $10(30)$ & $1.31 \pm 0.09$ & $5.55 \pm 0.21$ & $1.53 \pm 0.09$ & $0.27 \pm 0.09$ & $2.14 \pm 0.05^{1}$ & $219 \pm 5.11^{1}$ & -- & $73.3 \pm 5.17^{1,2}$ \\
\hline RW05-9/13-12:15 & Linnton & $45^{\circ} 33.065^{\prime}$ & $122^{\circ} 46.580^{\prime}$ & Qlo & $16(41)$ & $1.59 \pm 0.05$ & $11.3 \pm 0.31$ & $3.04 \pm 0.12$ & $0.17 \pm 0.02$ & $2.64 \pm 0.05^{3}$ & $124 \pm 13.6^{3}$ & $5(9)^{3}$ & $47.0 \pm 6.29^{3}$ \\
\hline RW05-9/13-14:00 & Dixie Mountain & $45^{\circ} 36.418^{\prime}$ & $122^{\circ} 51.792^{\prime}$ & $\begin{array}{l}\text { Roadcut in Qlo, } \\
1.9 \text { m below } \\
\text { surface }\end{array}$ & $2(38)$ & $1.09 \pm 0.06$ & $10.7 \pm 0.23$ & $2.57 \pm 0.10$ & $0.17 \pm 0.03$ & $2.13 \pm 0.04^{3}$ & $82.4 \pm 5.11^{3}$ & $13(20)^{3}$ & $38.7 \pm 3.01^{3}$ \\
\hline RW05-9/13-14:30 & Dixie Mountain & $45^{\circ} 36.418^{\prime}$ & $122^{\circ} 51.792^{\prime}$ & $\begin{array}{l}\text { Roadcut in Qlo, } \\
5.3 \mathrm{~m} \text { below } \\
\text { surface }\end{array}$ & 6 (39) & $1.16 \pm 0.06$ & $11.9 \pm 0.45$ & $3.22 \pm 0.22$ & $0.11 \pm 0.03$ & $2.34 \pm 0.06^{3}$ & $>185^{3}$ & $13(19)^{3}$ & $>79^{3}$ \\
\hline
\end{tabular}

${ }^{1}$ IRSL analysis.

${ }^{2}$ Anomalous fading experiments indicate fade of 10 to 11 percent, and this has been applied to calculated equivalent dose to calculate age.

${ }^{3}$ OSL analysis.

${ }^{4}$ Uncertainty reported as ranging from 0.02 to 0.06 . 
Table 4. Summary of radiocarbon age determinations, Sauvie Island quadrangle.

[All ages in years before present (B.P.) are referenced to A.D. 1950. Conventional corrected radiocarbon ages calculated on basis of Libby half-life of 5,568 years; 1- $\sigma$ error based on combined measurements of sample, background, and modern reference standards. Calibrated ages calculated on basis of CALIB 6.0 (http://calib.qub.ac.uk/calib/; accessed May 13, 2013) using INTCAL09 calibration data set (Reimer and others, 2009) and laboratory error multiplier of 1; where multiple intercepts calculated, we list solutions in order of greatest likelihood summing to $>90$ percent of probability density function. Two dashes (--) indicate sample is from units mapped in Sauvie Island quadrangle but collected in adjacent quadrangle. Samples analyzed in U.S. Geological Survey radiocarbon laboratory, Reston, Va., by J. McGeehin. Locations are in North American Datum of 1983 coordinates]

\begin{tabular}{|c|c|c|c|c|c|c|c|c|c|c|}
\hline \multirow[b]{2}{*}{$\begin{array}{c}\text { Map } \\
\text { no. }\end{array}$} & \multirow{2}{*}{$\begin{array}{l}\text { Field sample } \\
\text { no. }\end{array}$} & \multirow{2}{*}{$\begin{array}{l}\text { Lab } \\
\text { sample no. }\end{array}$} & \multirow[b]{2}{*}{ Quadrangle } & \multicolumn{2}{|c|}{ Location } & \multirow[b]{2}{*}{ Stratigraphic context } & \multirow[b]{2}{*}{ Material dated } & \multirow{2}{*}{$\begin{array}{l}\text { Conventional } \\
\text { age, in }{ }^{14} \mathrm{C} \text { yr } \\
\text { B.P. }\end{array}$} & \multirow{2}{*}{$\begin{array}{l}{ }^{13} \mathrm{C} /{ }^{12} \mathrm{C}^{1} \\
\pm 1-\sigma \\
\text { error }\end{array}$} & \multirow{2}{*}{$\begin{array}{l}\text { Calibrated 2- } \sigma \text { age ranges, in calendar yr } \\
\text { B.P. (fraction of probability density } \\
\text { function) }\end{array}$} \\
\hline & & & & $\begin{array}{l}\text { Latitude } \\
\mathrm{N} .\end{array}$ & $\begin{array}{l}\text { Longitude } \\
\text { W. }\end{array}$ & & & & & \\
\hline 1 & 9/13/09-9(1) & WW 3987 & Sauvie Island & $45^{\circ} 38.442^{\prime}$ & $122^{\circ} 46.415^{\prime}$ & $\begin{array}{l}\text { Within Qcws, beneath af, } \sim 6 \mathrm{~m} \\
\text { below surface }\end{array}$ & charcoal & $1,528 \pm 30$ & -25 & 1,349-1,447 (0.67); 1,454-1,518 (0.33) \\
\hline-- & 8/15/11-1(3) & WW 9122 & Saint Helens & $45^{\circ} 45.159^{\prime}$ & $122^{\circ} 49.159^{\prime}$ & $\begin{array}{l}\text { Within Qcwf, 3.8 m below } \\
\text { surface }\end{array}$ & charcoal clast & $2,130 \pm 30$ & 26.9 & 2,001-2,158 (0.89); 2,259-2,298 (0.11) \\
\hline-- & $8 / 15 / 11-1(7)$ & WW 9121 & Saint Helens & $45^{\circ} 45.173^{\prime}$ & $122^{\circ} 49.366^{\prime}$ & $\begin{array}{l}\text { Within Qcwf, 1.6 m below } \\
\text { surface, but stratigraphically } \\
\text { below 8/15/11-1(8) }\end{array}$ & charcoal clast & $1,160 \pm 30$ & -25.3 & $1,047-1,172$ (0.73); 981-1,036 (0.27) \\
\hline-- & 8/15/11-1(8) & WW 9120 & Saint Helens & $45^{\circ} 45.168^{\prime}$ & $122^{\circ} 49.367^{\prime}$ & $\begin{array}{l}\text { Within Qcwf, 2.1 m below } \\
\text { surface }\end{array}$ & $\begin{array}{l}\text { organic-rich } \\
\text { silt lamina }\end{array}$ & $390 \pm 35$ & -25 & 425-511 (0.68); 318-393 (0.35) \\
\hline
\end{tabular}

${ }^{113} \mathrm{C} /{ }^{12} \mathrm{C}$ not measured; value of $-25 \%$ (parts per thousand) assumed for determining conventional corrected age. 